\title{
The Psychometric Properties of the Persian Version of the Schizophrenia Caregiver Quality of Life Questionnaire
}

\author{
Sara Mokhtari ${ }^{1}$, Sayed Abbas Haghayegh ${ }^{2}$
}

\begin{abstract}
Background \& Aims: Schizophrenia is a severe psychological disorder that adversely affects the life quality of patients and their caregivers. In addition, life quality is a multidimensional and important index in determining the impact of the disease on the patient (18) and is assessed from two objective and mental aspects. It is the family of these patients who always incur the burden of support and care. Not only families must provide preliminary care (personal care and financial support) for patients, but also, they should adjust to the symptoms of the disease and accept and manage them. the Schizophrenia Caregiver Quality of Life Questionnaire encompasses significant experiences of Schizophrenia caregivers and is completely different from the conventional general quality of life questionnaires. The present study aimed to evaluate the psychometric properties of the Farsi version of the schizophrenia caregiver quality of life questionnaire (S-CGQoL).

Materials \& Methods: This psychological study was conducted on all the caregivers of schizophrenia patients in Isfahan, Iran in 2018. Caregivers of schizophrenia patients were selected via continuous sampling from three mental hospitals and three nursery centers during three months and were asked to fill the S-CGQoL by Richieri et al., which was translated in the present study, and the World Health Organization Quality of Life Questionnaire (WHOQOL) (Skevington et al.). The items of this tool are scored based on a five-point Likert scale from never $($ score $=1)$, to rarely $($ score $=2)$, sometimes $($ score $=3)$, often $($ score $=4)$ and always $($ score $=5)$. The S-CGQoL includes 25 items and evaluates seven dimensions of psychological and physical well-being (five items), psychological burden and daily life (seven items), relationships with spouse (three items), relationships with the psychiatric team (three items), relationships with family (two items), relationships with friends (two items) and material burden (three items). The total score is obtained from the sum of these questions, and higher scores in this questionnaire mean a higher quality of life. The tool was translated into Farsi by the translationretranslation method. In addition, the retest reliability of the instrument was assessed by asking 40 previous participants to refill the questionnaires after two weeks. Overall, 13 out of 40 individuals returned questionnaires and 27 tools were excluded due to being incomplete. The inclusion criteria were: 1) having a family member diagnosed with schizophrenia based on DSM.5, 2) being the main caregiver of a person with schizophrenia based on interviews and being the closest relative of the patient, and 3) giving full consent to participate in the research. On the other hand, the exclusion criterion was incomplete questionnaires. Reliability was assessed by the Cronbach's alpha method and split-half test. Following that, 200 questionnaires were distributed, 155 of which were returned. Data analysis was performed in SPSS version 24 and Amos version 21 using psychometric indexes such as confirmatory factor analysis (CFA), correlation coefficient and Cronbach's alpha.

Results: The results of the CFA indicated significant correlations between the factorial load of all the items in the S-CGQoL with the related factor $(\mathrm{P}<0.05)$ with relatively appropriate efficiency indices. Moreover, the results of internal reliability indicated the Cronbach's alpha range of 0. 54-0. 92 in various sub-indices of the questionnaire. The results of the retest reliability showed that Pearson's correlation coefficients for all the subindices of the S-CGQoL were significant in the two performed stages $(\mathrm{P}<0.05)$, with the overall correlation coefficient of 0.96 . In addition, the results of concurrent validity of the sub-indices of the SCGQoL with
\end{abstract}

1. MS Student in Clinical Psychology, Najafabad Branch, Islamic Azad University, Najafabad, Iran

2. Assistant Professor, Department of Psychology, Najafabad Branch, Islamic Azad University, Najafabad, Iran (Corresponding Author)

Tel: 031-42292770

Email:abbas_hghaghayegh@yahoo.com 
WHOQOL with the correlation-coefficient was significant $(\mathrm{P}<0.05)$ with a correlation coefficient of -0.56 , which means that there was a strong and reverse correlation between the two instruments. According to the retest correlation coefficient results, there was a significant correlation between the scores of the first and second implementations of the S-CGQoL $(\mathrm{P}<0.01)$. Furthermore, the reliability of the entire S-CGQoL was approved at a Cronbach's alpha of 0.92 and split-half of 0.78 .

Conclusion: According to the results, the Farsi version of the S-CGQoL had proper validity and reliability and could be used for the caregivers of patients with schizophrenia in the healthcare centers in Iran. Based on our findings, the overall score of the instrument with subscales of psychological and physical well-being, psychological burden and daily life, relationships with spouse, relationships with the psychiatric team, relationships with family, relationships with friends, and material burden had a favorable fit, and the questions were able to properly fit the factors related to themselves. According to the CFA and internal consistency of the S-CGQoL, the Farsi version of the instrument had construct validity and significant fit. It is suggested that the retest reliability of the tool be assessed at intervals longer than two weeks.

Key words: Questionnaire, Quality of Life, Caregivers, Schizophrenia, Reliability, Validity

\section{Conflict of Interest: No}

How to Cite: Mokhtari S, Haghayegh SA. The Psychometric Properties of the Persian Version of the Schizophrenia Caregiver Quality of Life Questionnaire. Iran Journal of Nursing. 2019; 32(120):71-86.

Received: 17 Jul 2019

Accepted: 22 Oct 2019 


\title{
بررسى ويزگى هاى روانسنجى نسخه فارسى بِرسشنامه كيفيت زندكى مر اقبين مبتلايان به اختلالات اسكيزوفرنى
}

\author{
سارا مختارى '، سيد عباس حقايق
}

\begin{abstract}
جكيده

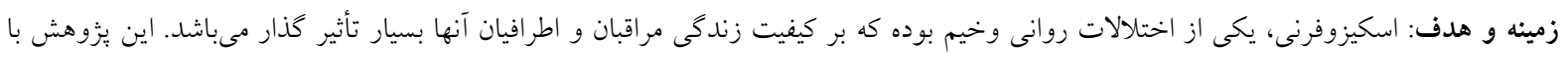

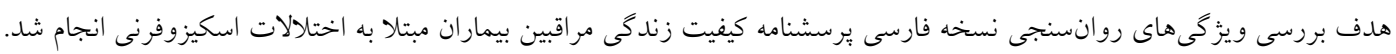

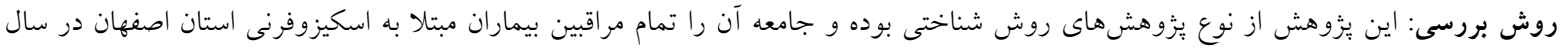

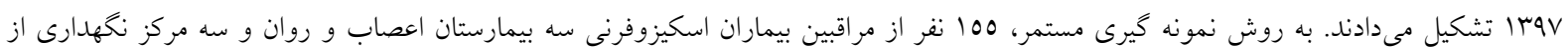

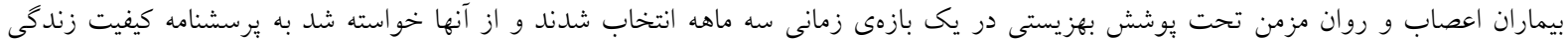

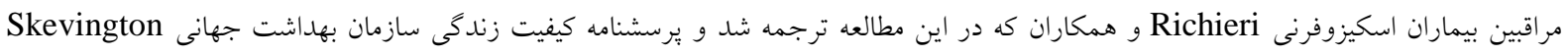

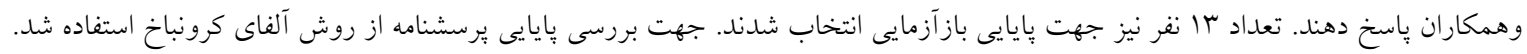

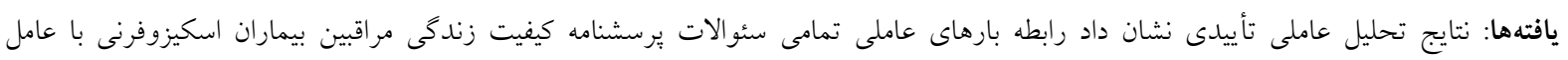

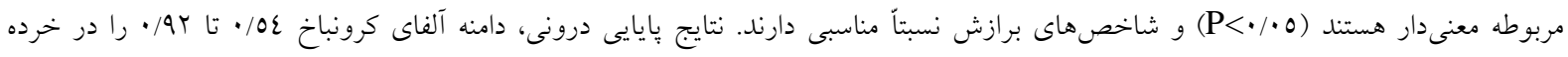

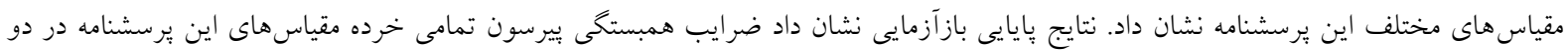

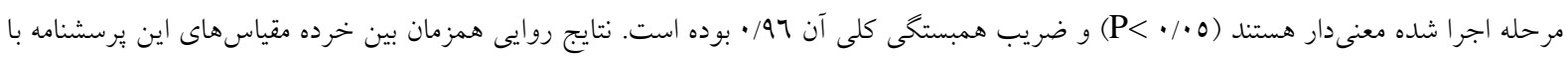

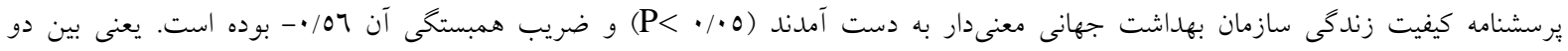

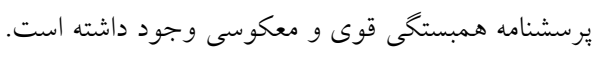

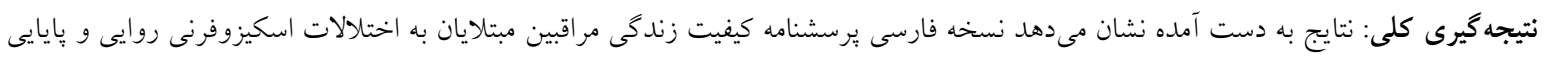

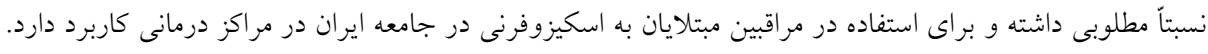

كليد وازهها: برسشناه،، كيفيت زندگى، مراقبين، اسكيزوفرنى، روايى، بايايى.

تعارض منافع: ن ندارد

تاريخ دريافت:

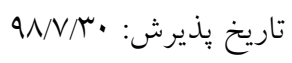

شمrqTRV+-+rT: شماره تماس

' ' دانشجوى كارشناسى ارشد روان شناسى بالينى، واحد نجف آباد، دانشعًاه آزاد اسلامى، نجف آباد، ايران. 
كزارش كردهاند كه توانايى آنها براى مراقبت از بيماران را

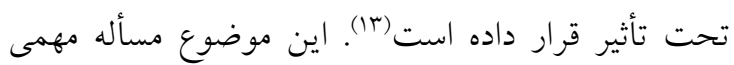
است به دليل اينكه حضور و دخالت مراقبينى كه جزء

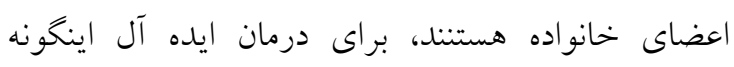
بيماران لازم و ضرورى است زيرا باعث مىشود در مورد يذيرش و قبول درمان، تداوم مراقبت و حمايت اجتماعى

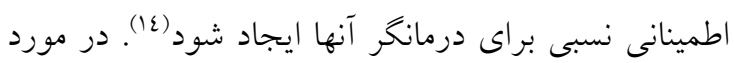
نحوهى ارتباط در اين بيماران به صورت گسترده مطالعه

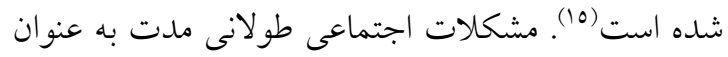
يك خصوصيت اصلى بيماران مبتلا به اسكيزوفرنى شناخته شده است (17). فقر اجتماعى، نقص در مراقبت از خود و مشكلات عملكردى و از كار افتادكى معيارهاى تشخيصى اسكيزوفرنى در اغلب سيستمهاى تشخيصى

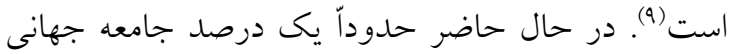
و نيم درصد جامعه ايرانى را بيماران اسكيزوفرنى تشكيل

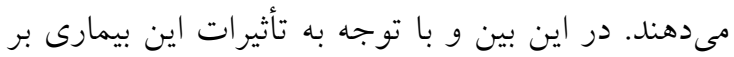

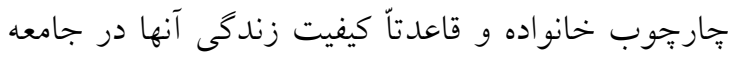
ى ايرانى، بر اساس آمار جهانى شاخص كيفيت زندأنى

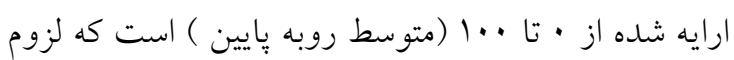

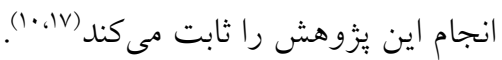

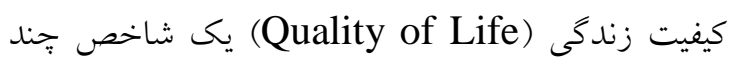
بعدى و مهم در تعيين تأثير خذارى بيمارى بر بيمار است(1) و از دو جنبه عينى و ذهنى مورد برررسى قرار

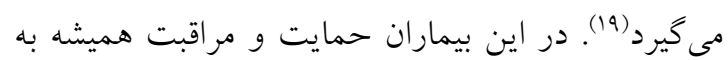
دوش خانواده مىافتد. خانوادهها نه تنها بايد مراقبتهاى اوليه (مراقبتهاى شخصى و حمايت مالى) را براى بيماران فراهم كنند، بلكه بايد بتوانند با علائم بيمار سازكارى حاصل نمايند و اين علائم و مشكلات را

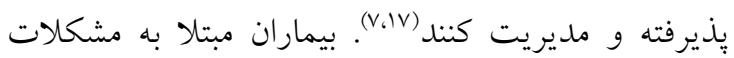
روانشناختى، جزيى از جامعه بوده كه متأسفانه كمتر مورد توجه قرار گرفته واغلب از سوى جامعه طرد مى شود،

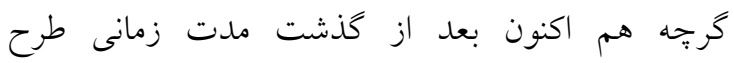

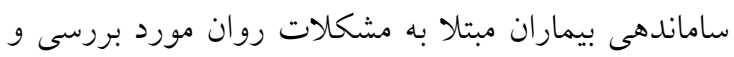

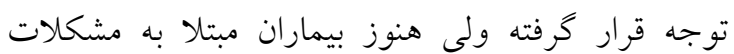

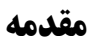
اسكيزوفرنى (Schizophrenia) يك اختلال روانى

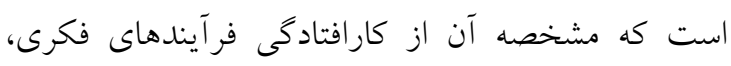

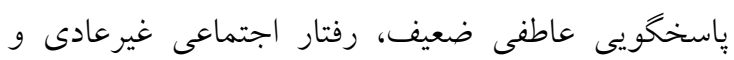

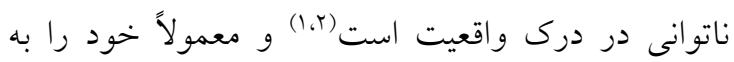
صورت توهمات، هذيانها يا تكلم و تفكر آشفته نشان

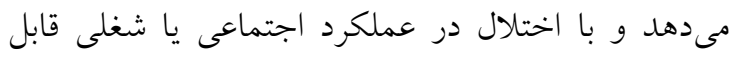
توجهى همراه است. اين اختلال فكر به صورت دشوارى

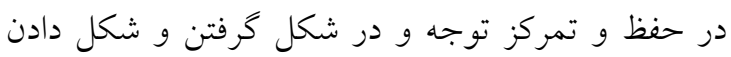

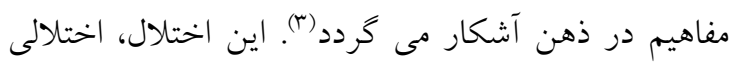
با علل جندكانه است كه مىتوان به نقش وراثت دهن (انتقال

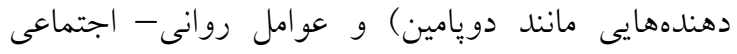
(ماند ساختار خانواده بيماركون) و... اشاره كرد كه فكر،

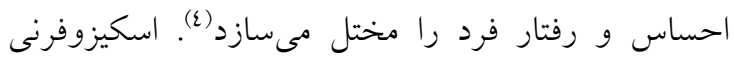

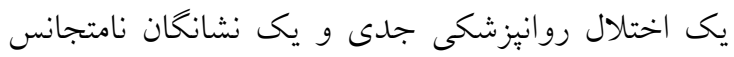

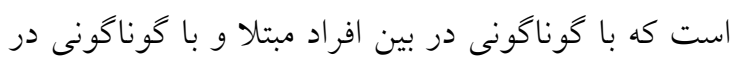

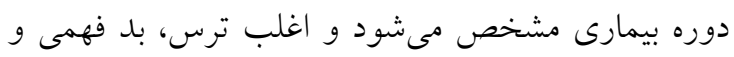

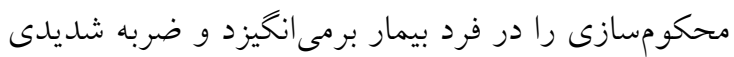

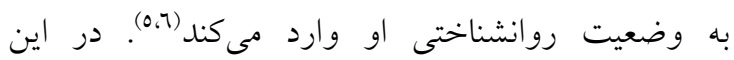
بيماران حمايت و مراقبت هميشه به دوش خانواده است.

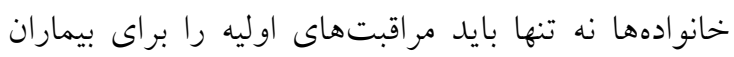

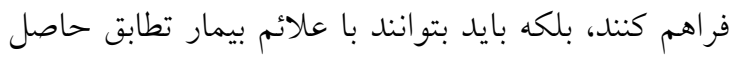

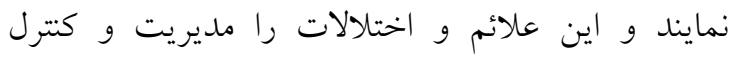

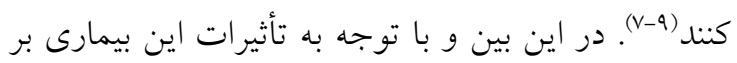

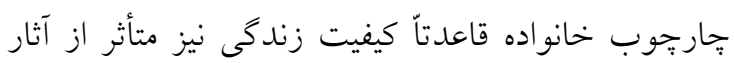

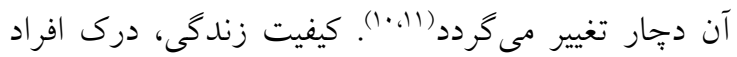

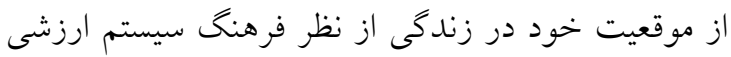
كه در آن زندگى مى كنند، اهداف، انتظارات و استانداردها

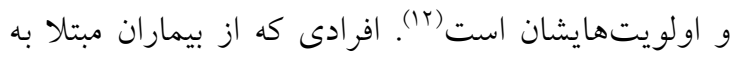

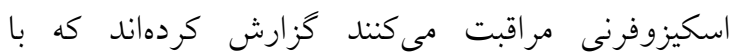
مشكلاتى مواجه شدهاند. اين افراد كاهش كيفيت زندكى به ويزه زمانى كه فشار زيادى را تحمل مئل كنند،

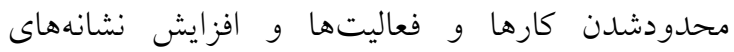
افسردگى، اضطراب و اختلالهاى روانى تنى زيادى را 
S- يرسشنامهاى عمومى كيفيت زندكى متداول مىباشد.

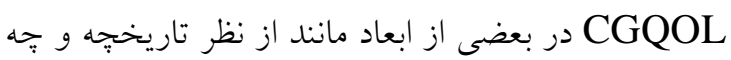

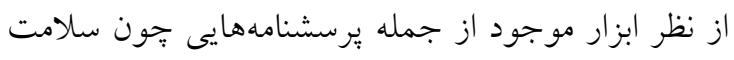

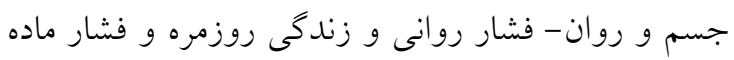

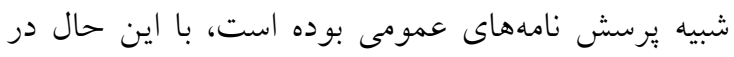
يرسشنامه اخير ابعاد نو و جديدى هم اضافه شده ازجمله

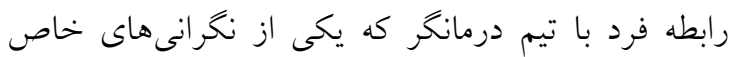
افراد مراقبت كننده از بيماران مبتلا به اسكيزوفرنى است. ارائه و فراهم نمودن فعاليتهاى حمايتى و خدماتى براى

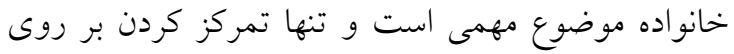
كاهش علائم بيمارى و يُيشخيرى از عود كردن بيمارى كافى نيست بلكه بايد برنامههاى درمانى و مداخله كرانه خانوادكى هم توسط تيمهاى خدمات سلامت ارائه شود (10). با توجه به اينكه ابزار اختصاصى سنجش كيفيت

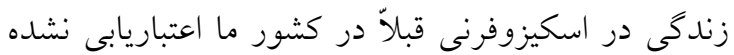
و نياز به اهميت جنين ابزارى، هدف يزوهش حاضر، تعيين مؤلفهاى روانسنجى نسخه فارسى S-CGQOL

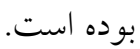

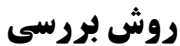

اين يُزوهش مطالعه اعتباريابى مىباشد. جامعه يُزوهش

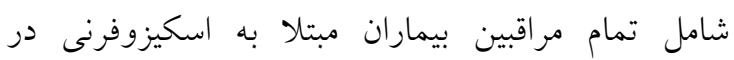
بيمارستان تخصصى روانيزشكى و مركز نخهدارى اعصاب و روان تحت يوشش بهزيستى شهر اصفهان در سال

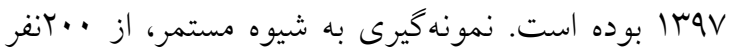
از مراقبين بيماران مبتلا به بيمارى اسكيزوفرنى در يك بازمى زمانى سه ماهه انتخاب شدند. يس از اخذ مجوز كميتهاخلاق (IR.IAU.NAJAFABAD.REC.1397.068) از معاونت يُوهشى دانشگاه آزاد نجف آباد و رضايت از شركت كنندگان، يُرسشنامه كيفيت زندكى مراقبين بيماران

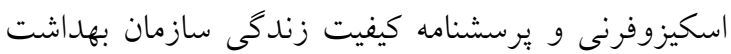

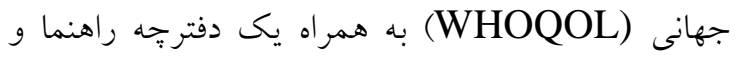

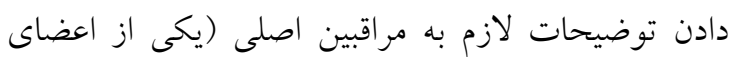

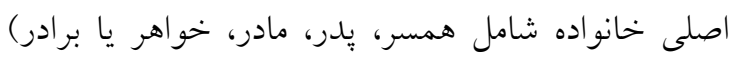

روانشناختى در موقعيت بسيار نامناسب بوده و حمايت

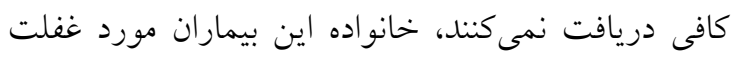

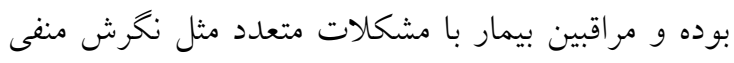

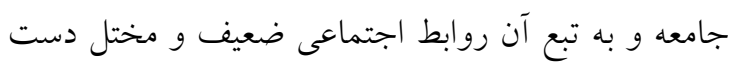

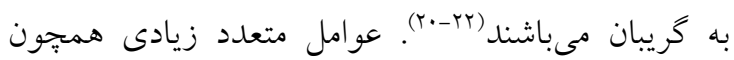

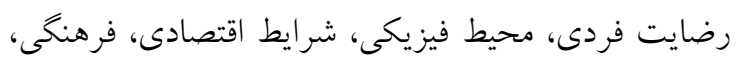
وضعيت سلامتى و عوامل فردى بر كيفيت زندكى افراد

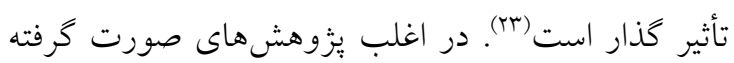

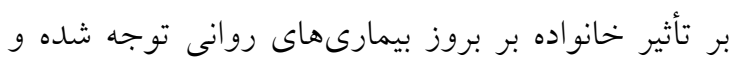

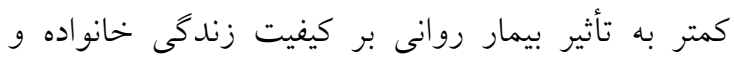

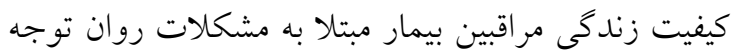

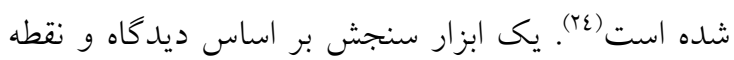

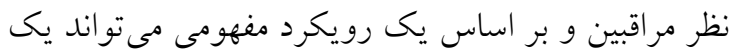
نوع آورى در حيطه تحقيق در زمينه بيمارى اسكيزوفرنى باشد. بررسى و ارزيابى كيفيت زندكى مراقبين مى تواند در بهبود سلامتى و بيماران مبتلا به اسكيزوفرنى، حفظ

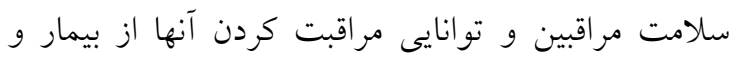

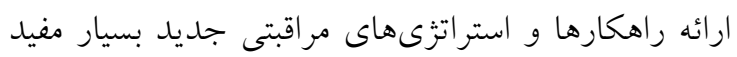

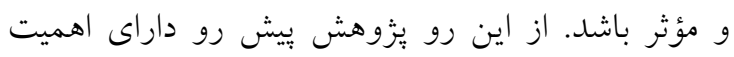

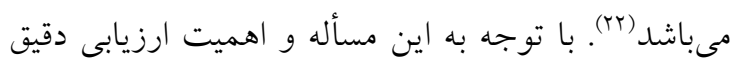

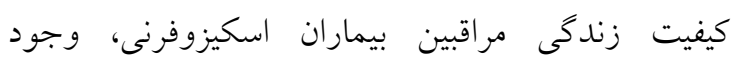
ابزارهاى داراى اعتبار ضرورى مىباشد. يرسشنامه كيفيت زندكى مراقبين بيماران اسكيزوفرنى دارئي (The Schizophrenia Caregiver Quality of ) Life: S-CGQOL

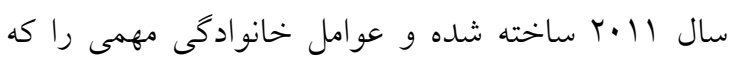
بايد موقع برنامه ريزىهاى مراقبتى براى فرد مبتلا به

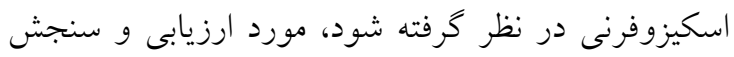

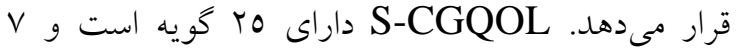

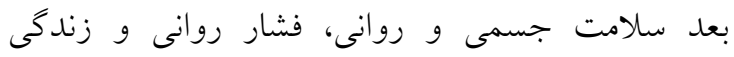
روزانه، ارتباط با همسر، ارتباط با تيم درمانخر روانى،

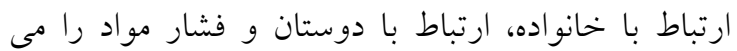

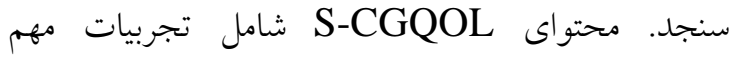
مراقبين بيماران اسكيزوفرنى بوده و كاملاً متفاوت از 
دهى داده شد. دادهاى جمع آورى شده وارد نرم افزارهاى آمارى SPSS نسخه استفاده از شاخصهاى روانسنجى شامل تحليل عامل

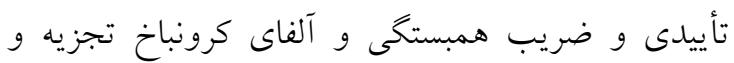
تحليل شد. ابزار گردآورى دادهها: يُرسشنامه كيفيت زندكى مر اقبين The Schizophrenia ) بيماران اسكيزوفرنى دردئن Caregiver Quality of Life Questionnaire: و Richieri S-CGQOL اين يرسشنامه توسط

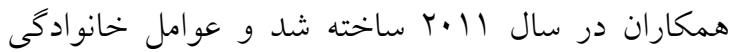
مهمى را كه بايد موقع برنامه ريزىهاى مراقبتى براى فرد

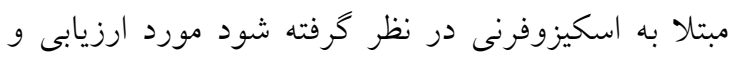

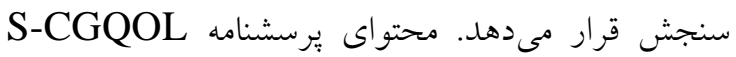
شامل تجربيات مهم بيماران اسكيزوفرنى بوده و كاملاً

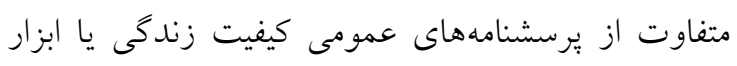

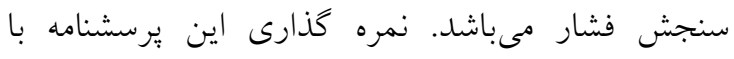

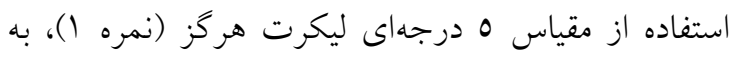

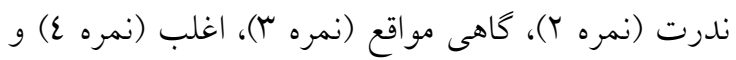

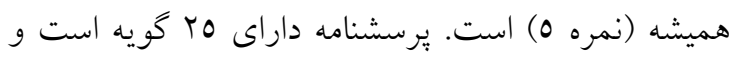

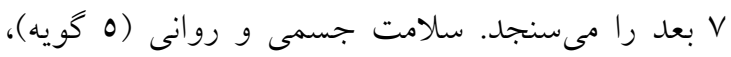

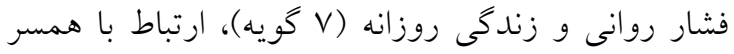

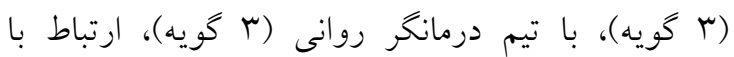
خانواده (r گ گيه)، ارتباط با دوستان (Y كويه) و فشار مواد (ب كويه). نمره كل از مجموع اين سئو الات به دست

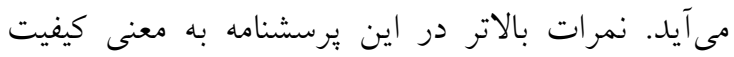

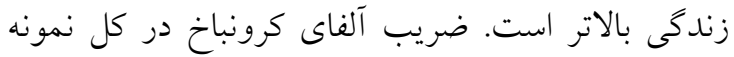

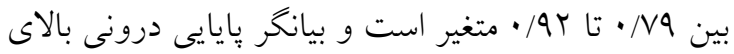
اين مقياس است كه در اين مطالعه ترجمه شده است (ro).

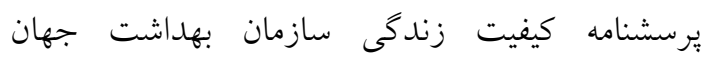
:(World Health Organization Questionnaire Quality of Life: WHOQOL) يكى از ابزارهاى عمومى كيفيت زندكى ابزار كيفيت

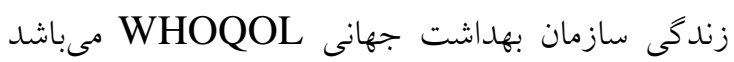
كه مفاهيم آن در فرهنگ هاى متفاوت يكسان است (بT)

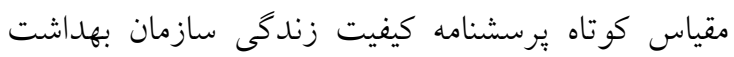

تحويل داده شد. از تعداد . . يرسشنامه، 100 مورد

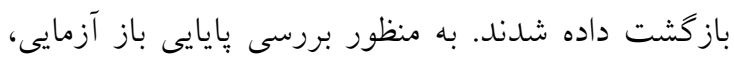

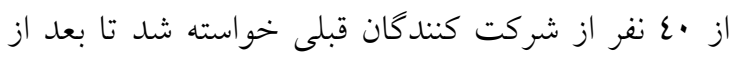

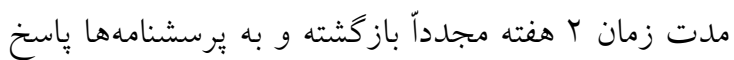

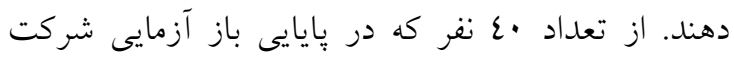

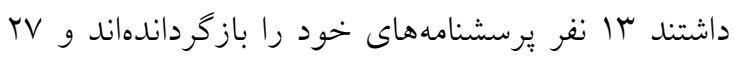
يرسشنامه نيز در اينجا بعلت پِاسخ ندادن به سئو الات فاقد بردات

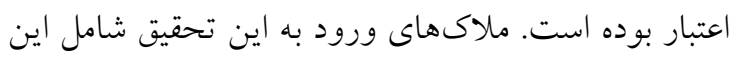
موارد بوده است: () داشتن فردى در بين اعضاى خانواده

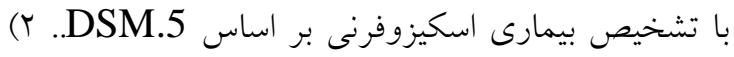
مراقب اصلى بودن فرد مبتلا به اسكيزوفرنى كه بر اساس مصاحبه و داشتن نزديكترين نسبت با بيمار تشخيص داده شد r) داشتن رضايت كامل براى شركت در تحقيق و و

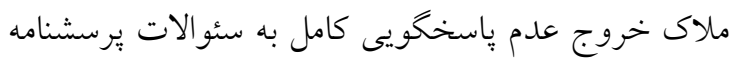

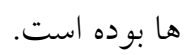
يرسشنامه اصلى مراقبين بيماران اسكيزوفرنى يس إز

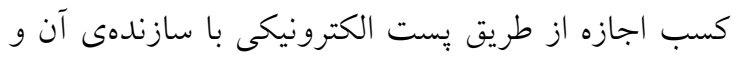

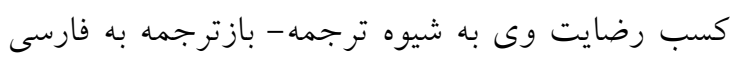

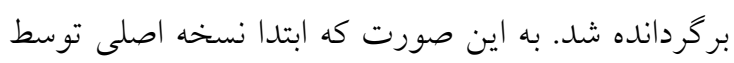

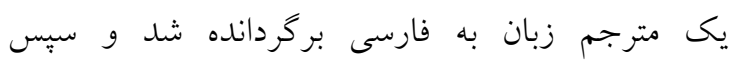

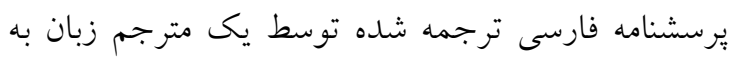
انخليسى بازترجمه شد كه نسبت به نسخهى اصلى بـ آكاه

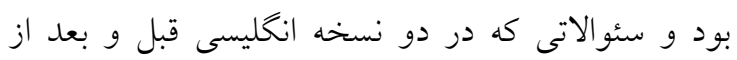

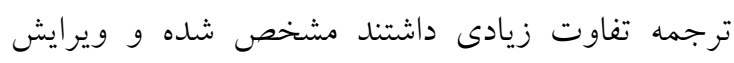
شد. به منظور بررسى روايى صورى، نسخه ترجمه شده به سه متخصص با مدرى دكترى روانشناسى داده شد تا

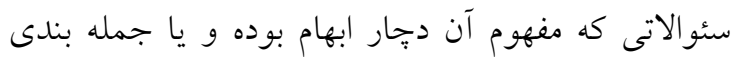
آن مناسب نيست را مشخص كنند. سئوالات T-V- سا عا-10-17 دجار ابهام تشخيص داده شده و به منظور

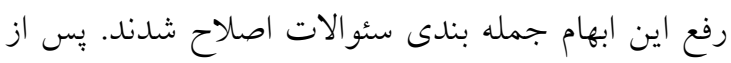

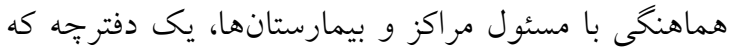

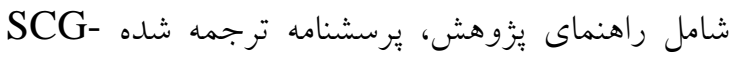

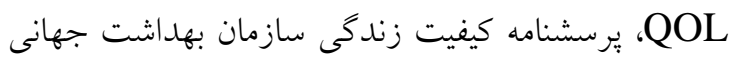

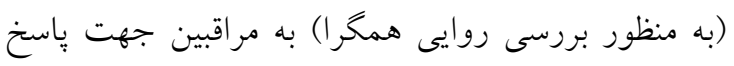


يُوهش حاضر برابر با AT/ • به دست آمد.

يافتهها

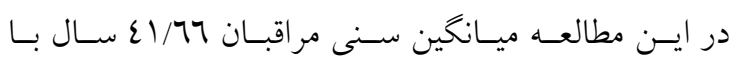

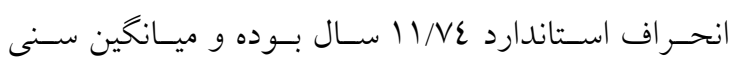

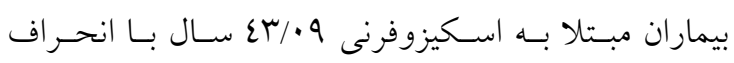

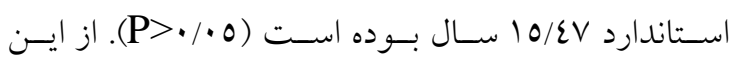

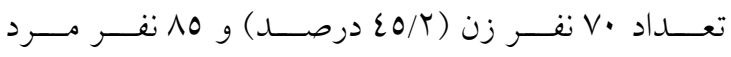

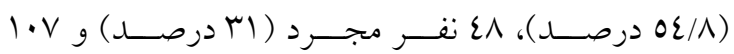

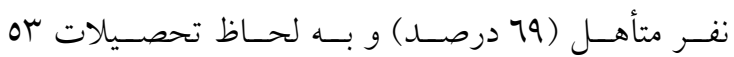

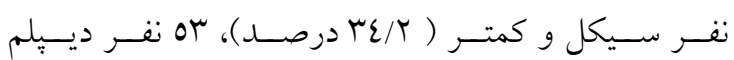

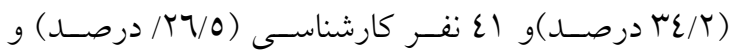

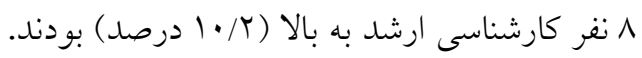

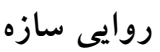
براى بررسى روايى سازه مقياس كيفيت زندكى مراقبين با باره

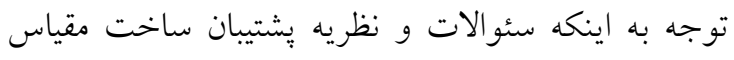
مشخص و معين است از تحليل عاملى تأييدى استفاده شد. بدين جهت ابتدا مدل بيشنهادى مقياس كيفيت زندگى مر اقبين در شكل شماره ا نشان داده شده است.
جهانى يس از ادغام برخى از حيطهها و حذف تعدادى از

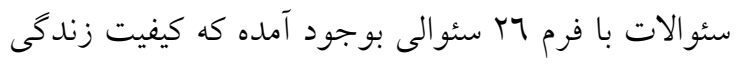

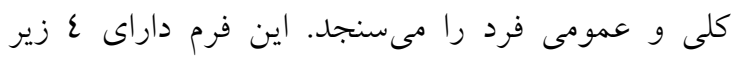
مقياس و يك نمره كلى است. اين زير مقياسها عبى عبارتند

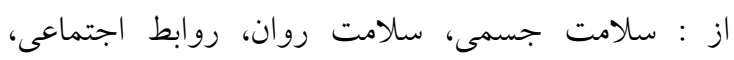

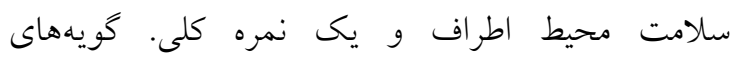

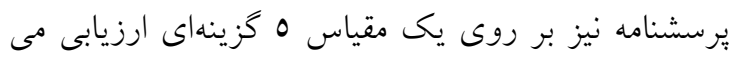
شود. در بررسى كويههاى نسخه كوتاه يرسشنامه نشان داده شده كه نمره ع حيطه بسيار WHOQOL شبيه نسخه بلند WHOQOL مىباشد. اين شباهت تا

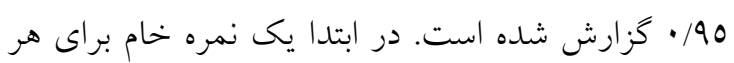

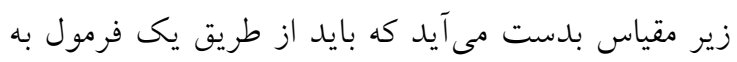

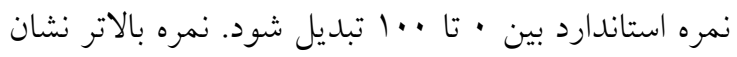
دهنده كيفيت زندكى بيشتر است. اين مقياس در سال 1997 توسط كروهى از كارشناسان سازمان بهداشت

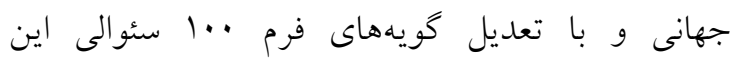

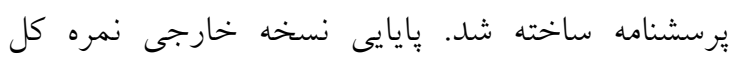

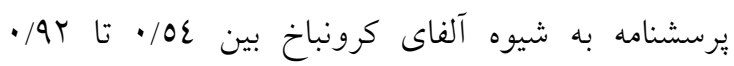

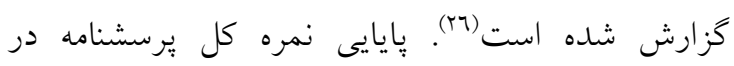

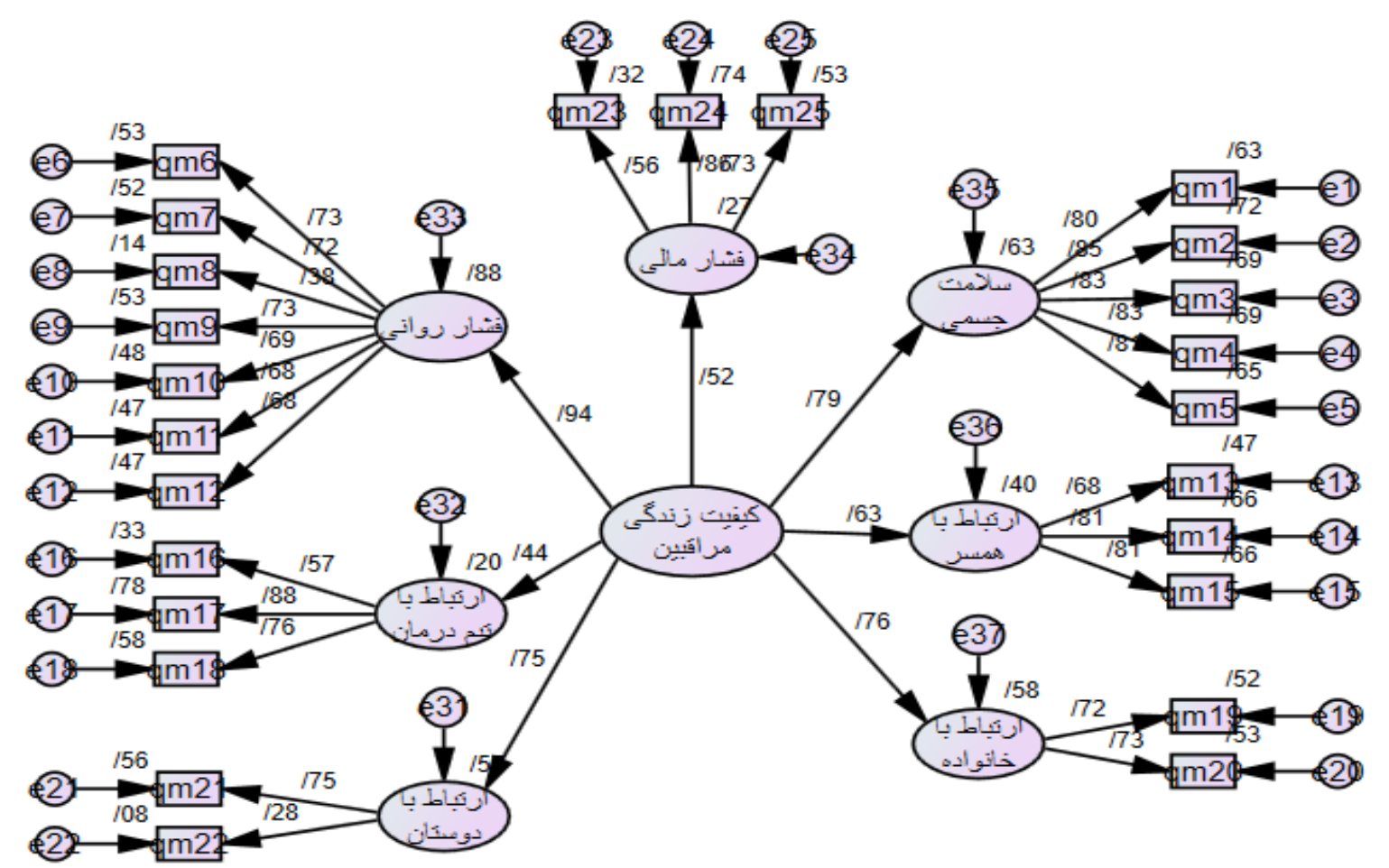

شكل شماره ا: مدل برازش شده مقياس كيفيت زندكى مراقبين اسكيزوفرنى 
زندگى روزمره با هفت سئوال، ارتباط با همسر با سه

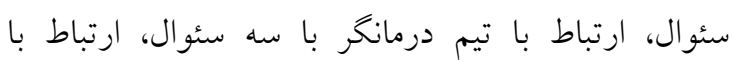

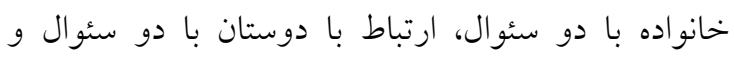

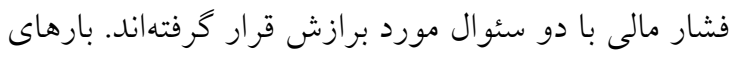
عاملى استاندارد شده، S.E. (خطاى استاندارد)، (نسبت بحران) و سطح معنىدارى ضرايب در جدول

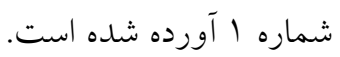

در اين معادله ساختارى سئوالات مربوط به هر عامل با يّيكان به مؤلفه مربوطه متصل شده است. ضرايب بار بار هر

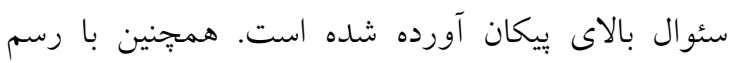
ييكانهايى از مقياس كل كيفيت زندكى مراقبين به مؤلفه هاى مقياس، تحليل عاملى مرتبه دوم نيز رسم و مورد

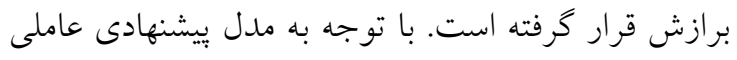

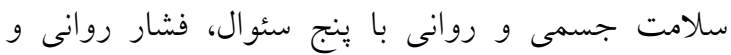

جدول شماره ا: بارهاى عاملى استاندارد شده خطاى استاندارد ميانغَين و نسبت بحران و سطح معنىدارى سئوالات

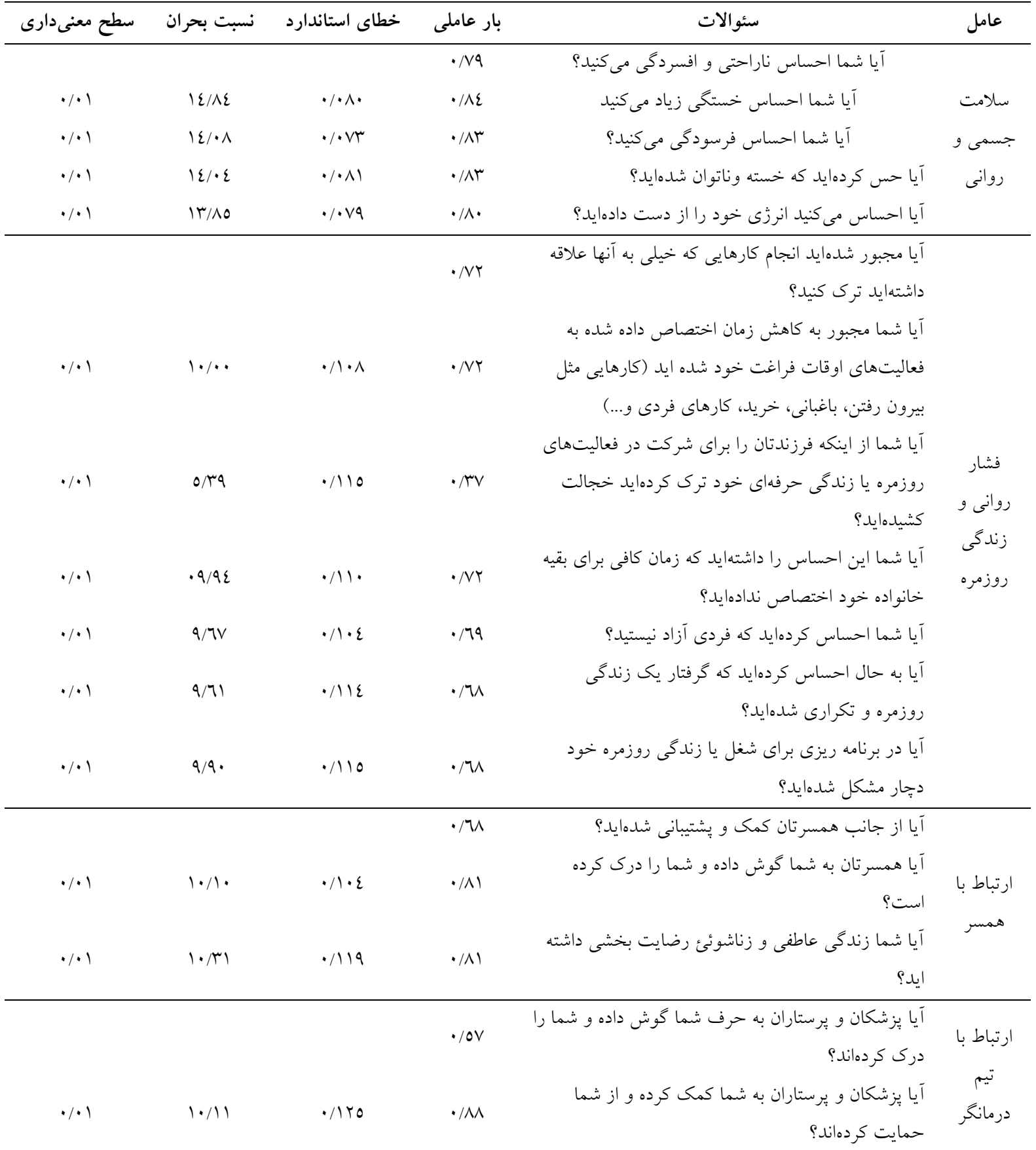




\begin{tabular}{|c|c|c|c|c|c|}
\hline$\cdot / \cdot 1$ & N/Tr &.$/ .97$ & $\cdot /$ No & راضيا از اطلاعات داده شده توسط يزشكان و يرستاران & \\
\hline$\cdot / \cdot 1$ & $\Lambda / \cdot 1$ & $\cdot / I T V$ & $\cdot \cdot N T$ & 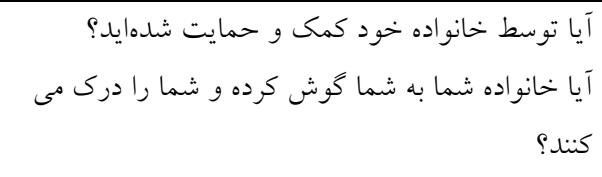 & 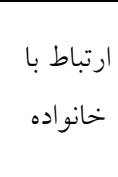 \\
\hline$\cdot / \cdot 1$ & $r / \cdot 0$ & $\cdot / 9 \varepsilon 9$ & $\cdot / r \Lambda$ & كَيا كندا دوستانتان به شما كمك كرده و از شما حمايت مى & ارتباط بان \\
\hline & & & $\cdot / 07$ & 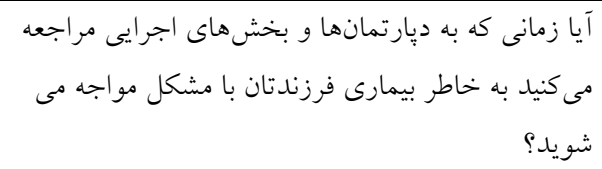 & \\
\hline$\cdot / \cdot 1$ & V/VA & $\cdot / T / \Lambda$ & $\cdot / 17$ & ايدي با به خاطر بيمارى فرزندتان با مشكل مالى مواجه شده & فشار مالى \\
\hline$\cdot / \cdot 1$ & $V / 04$ & $\cdot / r \cdot r$ & .NY & 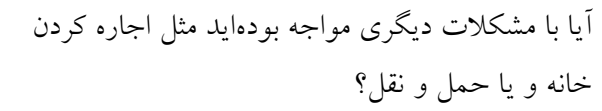 & \\
\hline
\end{tabular}

است سئوال كمى تغيير كند. با اين وجود تمامى بارهاى

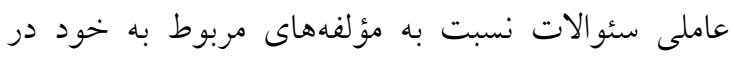

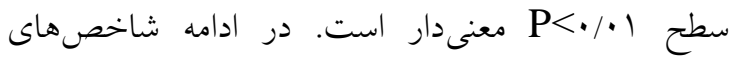
برازش مدل تحليل عاملى تأييدى مدل نهايى در جدول شماره r آورده شده است.

با توجه به جدول شماره 1 تمامى مقادير ضرايب

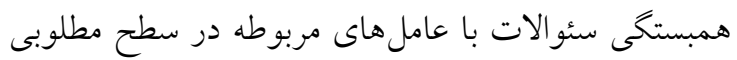

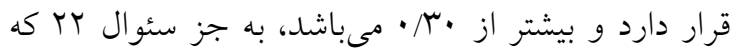
به اين علت كه مؤلفه ارتباط با دوستان تنها از دو سئوال تشكيل شده است امكان حذف سئوال نبوده است و بهتر

جدول شماره ז: شاخصهاى برازش مدل تحليل عاملى تأييدى

\begin{tabular}{|c|c|c|c|c|c|c|c|c|c|}
\hline \multicolumn{3}{|c|}{ آزمون كاى اسكوئر } & \multicolumn{7}{|c|}{ شاخص برازندگى } \\
\hline سطح معنى دارى & درجه آزادى & مقدار & RMSEA & $\mathrm{CFI}$ & NFI & IFI & TLI & AGFI & GFI \\
\hline$\cdot / \cdot v$ & rus & $1 / 00$ & $\cdot / \cdot 1$ & $\cdot / 9 T$ & $\cdot / \Lambda \Lambda$ &.$/ 9 Y$ & $\cdot / 9$. & $\cdot / \mathrm{AV}$ & $\cdot / 199$ \\
\hline
\end{tabular}

زندگى مراقبين را برآورد نمايند. همجنين خطاى اندازه

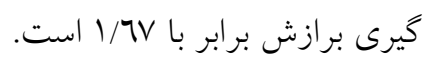

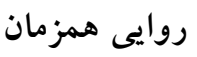

جهت بررسى روايى همزمان مقياس كيفيت زندكى دمان مراقبين، همزمان با توزيع مقياس بر روى اعضاى گروه نمونه، مقياس كيفيت زندكى سازمان بهداشت جهانى نيز به افراد داده و اين مقياس نيز مورد سنجش قرار كرفت. پِ از تكميل دو نسخه يرسشنامه در جدول شماره بَ به
با توجه به شاخصهاى برازش آورده شده در جدول

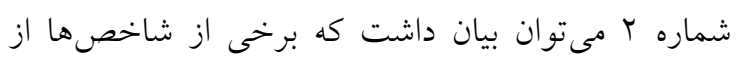

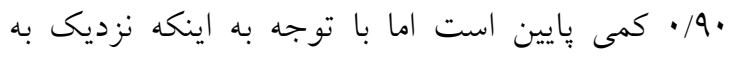

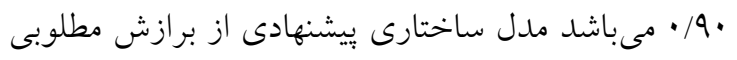

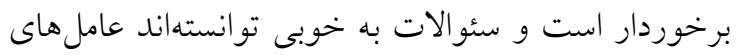

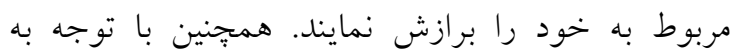

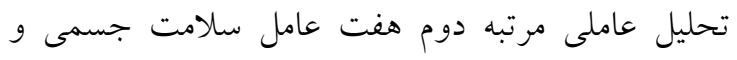
روانى، فشار روانى و زندگى روزيه دومعره، ارتباط با همسر،

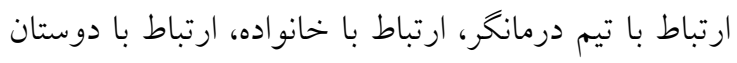

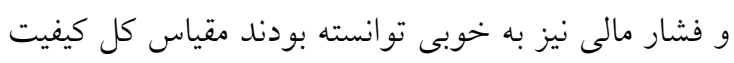




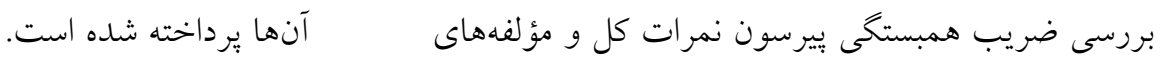

جدول شماره س: ضرايب همبستكى مقياس كيفيت زندكى مراقبين بيماران اسكيزوفرنى با مقياس كيفيت زندكى

\begin{tabular}{|c|c|c|c|c|c|}
\hline محيط زندگى & روابط اجتماعى & سلامت روان & سلامت جسمى & كل كيفيت زندگى & مقياس \\
\hline$+\cdot / 0 \cdot * *$ & $+\cdot / 01 * *$ & $+\cdot / \varepsilon r * * *$ & $+\cdot / \Lambda$ 米* & $+\cdot 107 * * *$ & كل كيفيت زندكى مراقبين \\
\hline$+\cdot / \Lambda$ 八** & $+\cdot / \varepsilon r^{*} * *$ & $+\cdot / r q * * *$ & $+\cdot \Gamma \wedge * * *$ & $+\cdot / 乏 \wedge * * *$ & سلامت جسمى \\
\hline$+\cdot / \varepsilon 9 * *$ & $+\cdot / 乏 \wedge * * *$ & $+\cdot / 20 * * *$ & $+\cdot \pi 0 * *$ & $+\cdot 10\{* *$ & فشار روانى \\
\hline$+\cdot / \Upsilon \wedge * * * *$ & $+\cdot / r 9 * * *$ & $+\cdot / r \cdot * * * *$ & $+\cdot / 1 \Gamma *$ & $+\cdot / r 9 * * *$ & ارتباط با همسر \\
\hline$+\cdot / 1 \Gamma *$ & $+\cdot / r O * * *$ & $+\cdot / / V * *$ & $+\cdot / / \varepsilon *$ & $+\cdot / r \cdot * * *$ & ارتباط با درمانگر \\
\hline$+\cdot / \mu \cdot * * *$ & $+\bullet /$ & $+\cdot / \curlyvee \wedge$ *** & $+\cdot / r 0 * *$ & $+\cdot / \Gamma า$ 药* & ارتباط با خانواده \\
\hline$+\cdot / T \mid * * *$ & $+\cdot / Y 0 * *$ & $+\cdot / r \cdot * * * * *$ & $+\cdot / \Upsilon 7 * * *$ & $+\cdot / \Gamma 1$ 米米 & ارتباط با دوستان \\
\hline$+\cdot / 20 * *$ & $+\cdot / Y V * * *$ & $+\cdot / l V$ 䅈米 & $+\cdot / 10 *$ & $+\cdot / \Gamma 0 * * *$ & فشار مالى \\
\hline
\end{tabular}

خانواده، ارتباط با دوستان و فشار مالى نيز رابطه معنى دارى با مقياس كيفيت زندگى و مؤلفهاى سلامت جسمى، سلامت روان، روابط اجتماعى، محيط زندگى داشته|ند (P</ (P) پايايى بازآزمايى

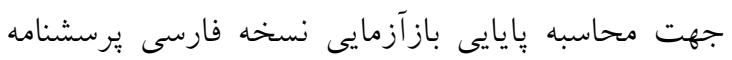

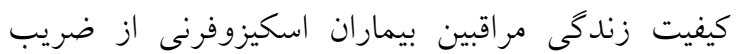
همبستخى بين اجراى اول مقياس كيفيت زندكى مراقبين

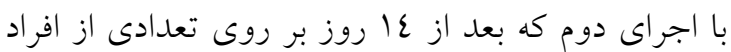
كروه نمونه مجدد اجرا شده استفاده شده است. نتايج ضرايب همبستخى ييرسون اجراى اول و دوم در جدول

$$
\text { شماره ع آورده شده است. }
$$

با توجه به جدول شماره ؟ مىتوان بيان داشت كه خرده مقياسهاى كيفيت زندگى مراقبين بيماران اسكيزوفرنى رابطه معنى دارى با مقياس كيفيت زندكى سازمان بهداشت جهانى داشته است، يرسشنامه كيفيت زندكى سازمان

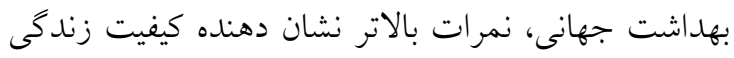

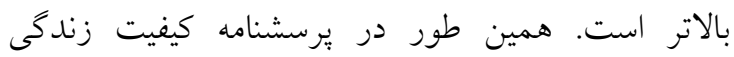

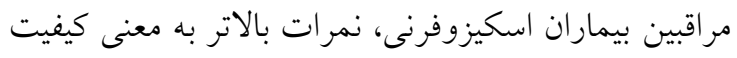

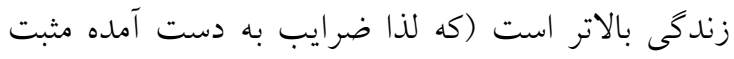

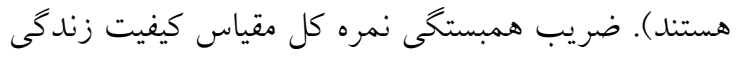

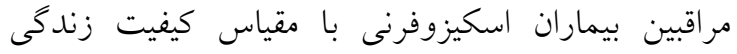
سازمان بهداشت جهانى برابر با 07 • بوده است. همجنين مؤلفههاى سلامت جسمى و روانى، فشار روانى و زندكى

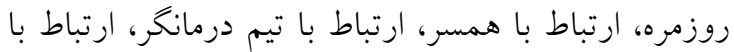
جدول شماره ع: ضرايب همبستكى پايايى بازآزمايى بر سشنامه كيفيت زندكى مراقبين

\begin{tabular}{|c|c|c|c|c|}
\hline خطاى معيار اندازه گيرى & ضريب پِيايیى بازآزمايى & انحر اف معيار & ميانغين & 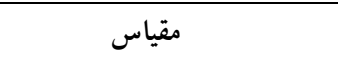 \\
\hline$\mu / \mu$ & $\cdot / 97 * *$ & $\mid V / \mu \Lambda$ & $70 / 9 T$ & نمره كل كيفيت زندگى مراقبين \\
\hline $1 / r r$ & $\cdot / 9 \Gamma * * *$ & $0 / \cdot 1$ & $1 \% / 0 \varepsilon$ & سلامت جسمى \\
\hline $1 / \cdot r$ & $\cdot / 9 V * * *$ & $\tau / \cdot r$ & $19 / 70$ & فشار روانى \\
\hline $1 / 17$ & $\cdot / 19 * * *$ & $r / \varepsilon V$ & $V / l \varepsilon$ & ارتباط با همسر \\
\hline$\cdot / N r$ & $\cdot / 9 \varepsilon \div$ & $r / 97$ & $\mathrm{~V} / \cdots$ & ارتباط با درمانگر \\
\hline 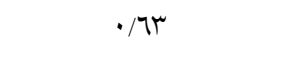 & $\cdot / 9 \cdot * * *$ & $r / \cdot r$ & $\varepsilon / V \wedge$ & ارتباط با خانو اده \\
\hline$\cdot / 19$ & $\cdot / \mathrm{N}$ **** & $1 / 9$ & $0 / 1$ & ارتباط با دوستان \\
\hline$\cdot / \wedge \varepsilon$ & $\cdot / 9 Y * * *$ & $r / \Lambda$ & $\Lambda / \nearrow \vee$ & ل \\
\hline
\end{tabular}


اختلال اسكيزوفرنى انجام شد. بر اساس نتايج كلى

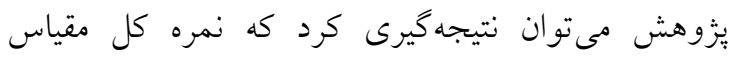

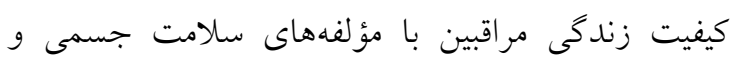

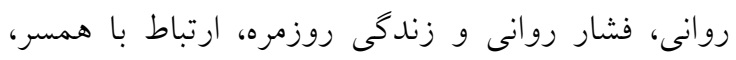

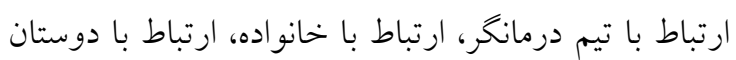

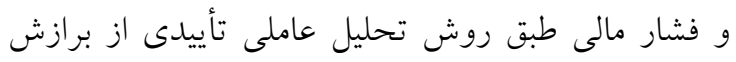
مطلوبى برخوردار است و سئوالات به خوبى توانستهاند

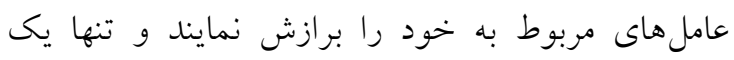

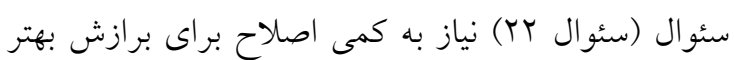

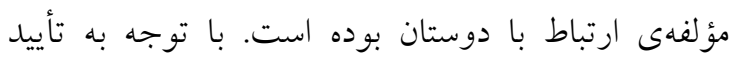
تحليل عاملى تأييدى و همسانى درونى مقياس كيفيت

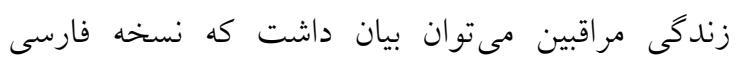
يرسشنامه كيفيت زندكى مراقبين بيماران اسكيزوفرنى از بران روايى سازه و برازش معنىدارى برخوردار است. نتايج

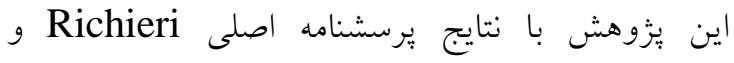

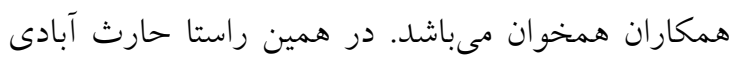

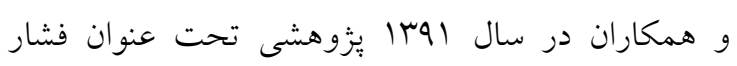
روانى مراقبين بيماران اسكيزوفرنى بسترى در بيمارستان

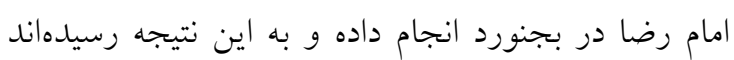

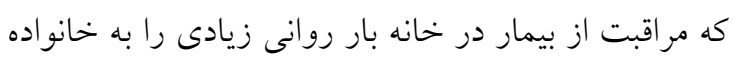

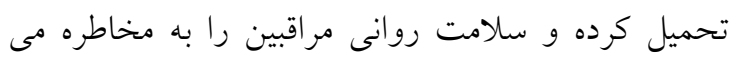

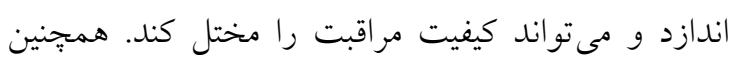
Magliano در آن عذاب ناشى از مراقبت يك بيمار مزمن در دو كروه

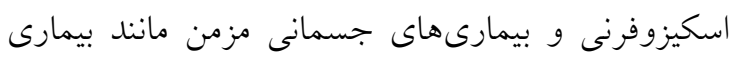
هاى ريوى و قلبى و مغزى مقايسه شده، نشان دادند كه ونه

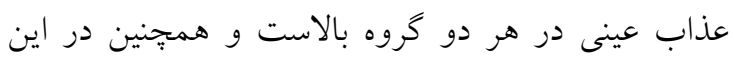

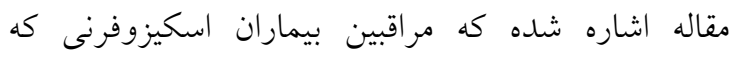
حمايت اجتماعى كمترى داشتند عذاب بيشترى گزارش

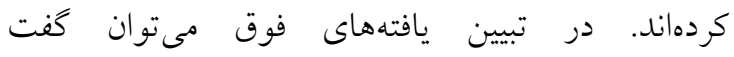

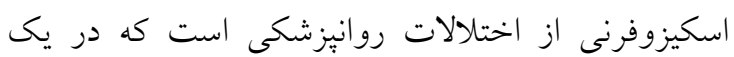
درصد افراد جامعه ديده مىشود و به كونهاى است كه

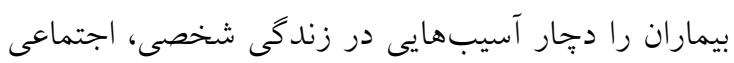

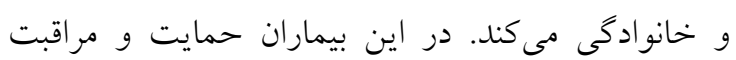

با توجه به جدول شماره ع نتايج ضريب همبستخى

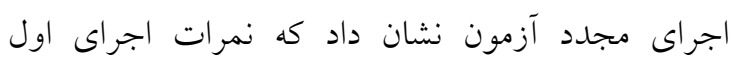

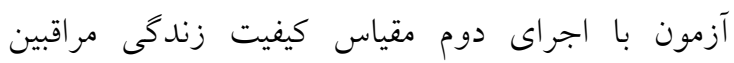
بيماران اسكيزوفرنى همبستكى معنى دارى وجود دوم دارد . $(\mathrm{P}<\cdot / \cdot 1)$

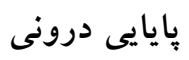
نتايج يايايى درونى يرسشنامه در جدول شماره

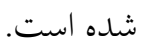
جدول شماره 0: ضرايب پايايیى مقياس كيفيت زندكى مراقبين

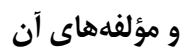

\begin{tabular}{|c|c|c|}
\hline دو نيمه كردن & آلفاى كرانباخ & مقياس \\
\hline$\cdot / \mathrm{V} \wedge$ & $\cdot / 9 r$ & كل كيفيتزندگى مر اقبين \\
\hline$\cdot / 19$ & $\cdot / 91$ & سلامت جسمى \\
\hline$\cdot / \wedge \cdot$ & $\cdot / \wedge \varepsilon$ & فشار روانى \\
\hline$\cdot / \Lambda \mu$ & $\cdot / 11$ & ارتباط با همسر \\
\hline$\cdot / \mathrm{Na}$ & $\cdot / \mathrm{VA}$ & ارتباط با درمانخر \\
\hline$\cdot / 79$ & $\cdot / 79$ & ارتباط با خانو اده \\
\hline$\cdot / 0 r$ & $\cdot / 0 \varepsilon$ & ارتباط با دوستان \\
\hline . NO & $\cdot / v \varepsilon$ & فشار مالى \\
\hline
\end{tabular}

با توجه به جدول شماره 0 ضريب پايايى مقياس كل

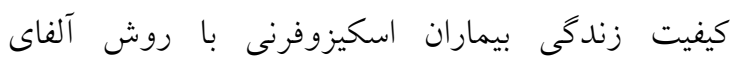

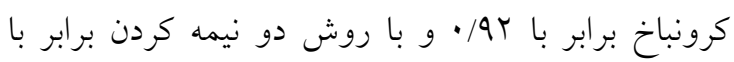

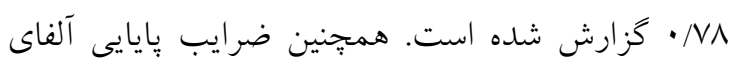
كرونباخ و ضريب بايايى دو نيمه كردن مؤلفهاى مقياس

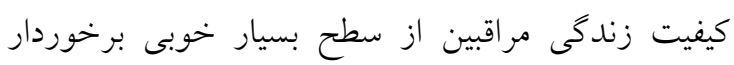

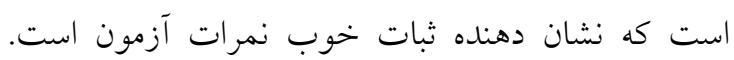

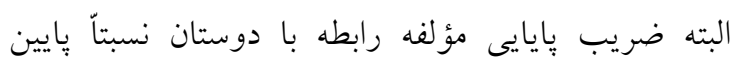

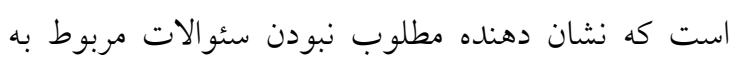
اين خرده مقياس است.

\section{بحث و نتيجهَيرى}

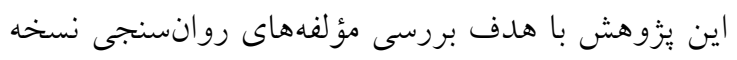

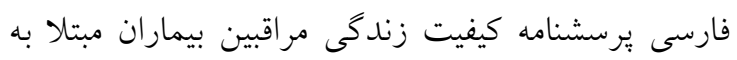


طبق نتايج جدول شماره 0، ضريب يايايى مقياس كيفيت

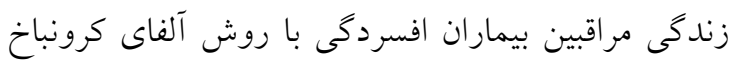

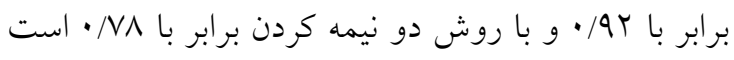

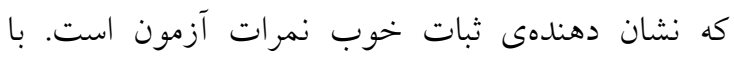

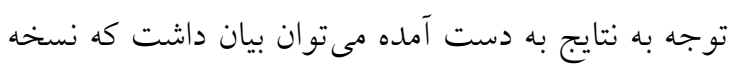

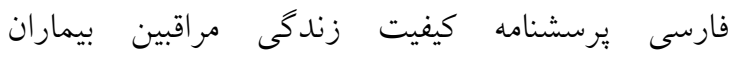
اسكيزوفرنى از پايايى درونى خوبى برخوردار است. اين

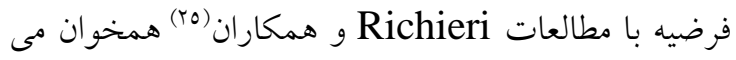

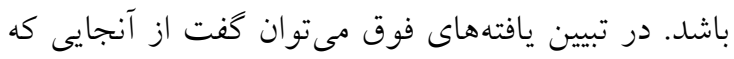

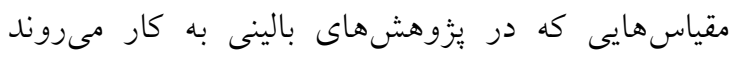

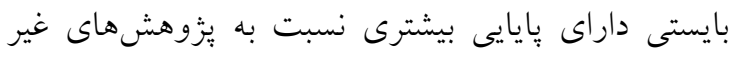

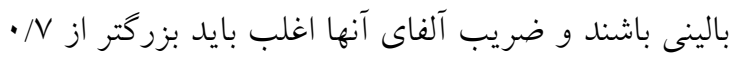
باشد و به دليل اينكه ضريب پايايى بيشتر مؤلفهها نسبتاً بالا است، بنابر اين نشان دهنده اين است كه اين يرسشنامه

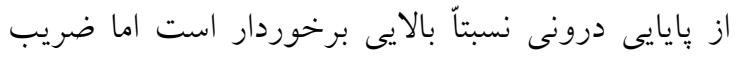

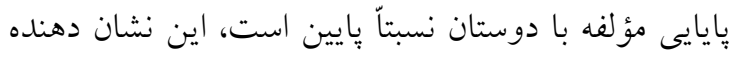

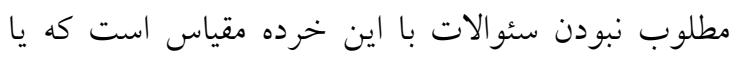

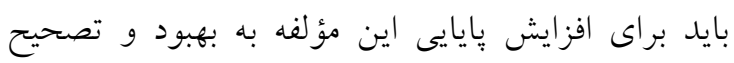

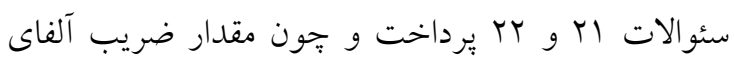
كرونباخ يك مقياس با افزايش تعداد كويههاى آن مؤلفه

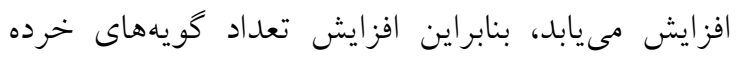

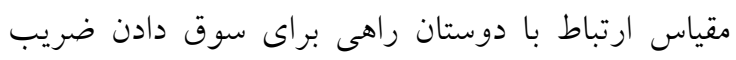

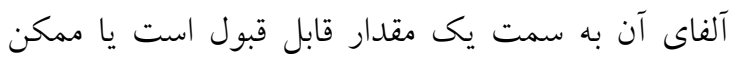

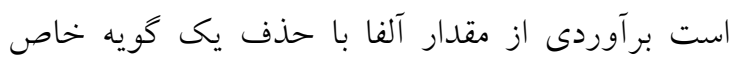

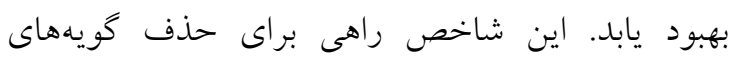

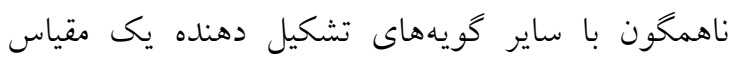

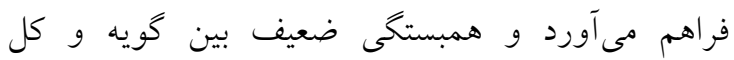
مقياس نشان دهنده كويهاى است كه مىتواند كانديداى حذف باشد، بنابراين مىتوان كويه ارتباط با دوستان را نيز حذف كرد. به طور كلى تمامى مؤلفههاى كيفيت زندكى مراقبين به غير از ارتباط با دوستان داراى كويههاى بيشتر هستند، بنابر اين بايايى بيشترى دارند.

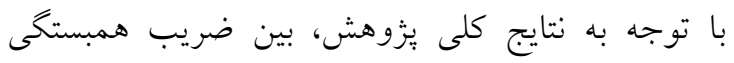

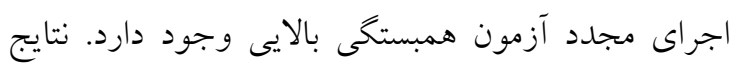

هميشه به دوش خانواده مى افتد. خانوادهها نه تنها بايد

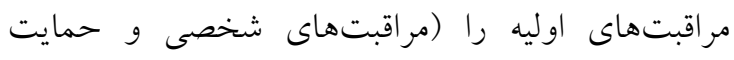

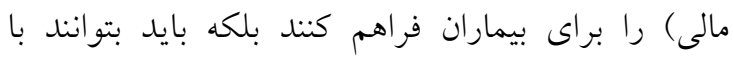

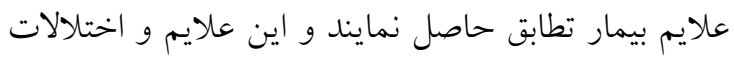

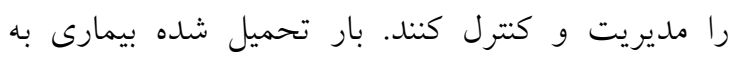
خانواده شامل مشكلات جسمانى، روانى و اقتصادى است كه به وسيله فردى كه از بيمار خانواده خود در خانه

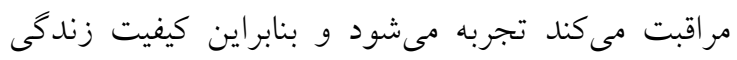

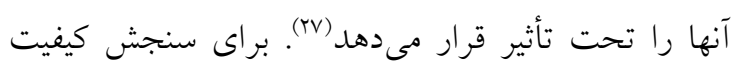
زندكى اين افراد برسشنامهايى تهيه شده كه تمام بارهاى تصاي

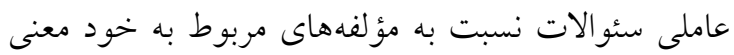

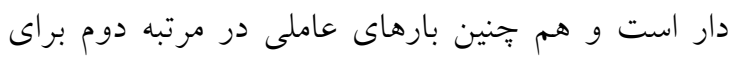

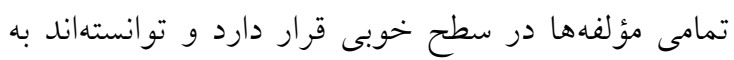
خوبى نمره كل مقياس كيفيت زندكى را تبيين كنند. هم

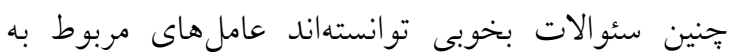

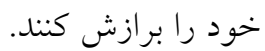

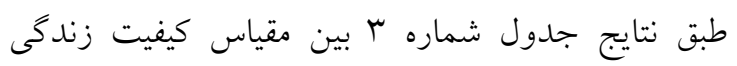
مراقبين همبستكى نمره كل مقياس كيفيت زندكى مر اقبين

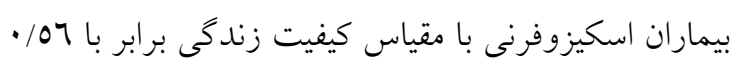

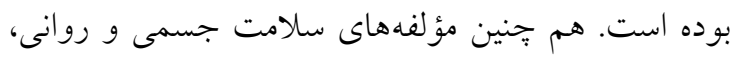

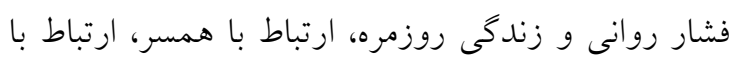

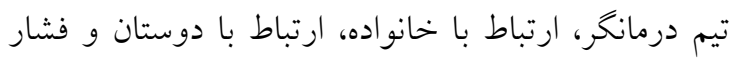

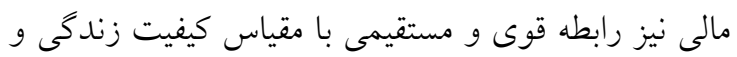

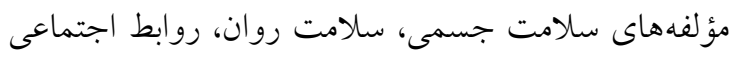

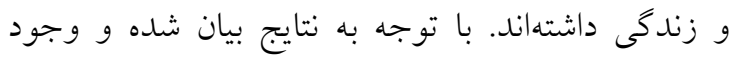

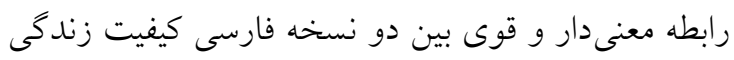

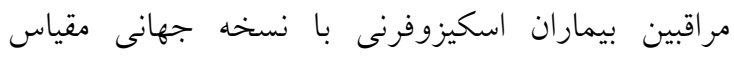
كيفيت زندكى سازمان بهداشت جهانى مىتوان بيان داشت كه نسخه فارسى :رسشنامه كيفيت زندكى مراقبين بيماران اسكيزوفرنى از روايى همزمان معنىدار برخوردار است. در تبيين يافتههاى فوق مىتوان كفت شدت رابطه بدين جهت است كه نمرات مقياس كيفيت زندگى مراقبين بيماران اسكيزوفرنى و مؤلفه هاى آن به صورت مستقيم تفسير مىشود. 


$$
\begin{aligned}
& \text { اصلى مطابقت دارد و از آن مىتوان به عنوان يك ابزار } \\
& \text { سنجش كيفيت زندگى معتبر در ايران استفاده كرد. انجام }
\end{aligned}
$$

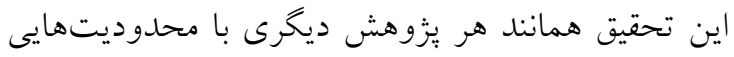

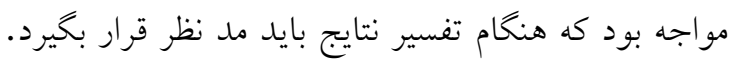

$$
\begin{aligned}
& \text { يافتهاى مطالعه حاضر مربوط به مراقبين بيماران }
\end{aligned}
$$

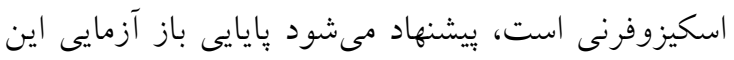

$$
\begin{aligned}
& \text { يرسش نامه در فواصل طولانىتر بيش از دو هفته بررسى } \\
& \text { كردد. }
\end{aligned}
$$$$
\text { تعارض منافع: هيج تعارض منافعى توسط نويسندكان بيان }
$$$$
\text { نشده است. }
$$

\section{تقدير و تشكر}

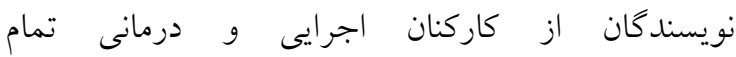
بيمارستانهاى داراى بخش روانيزشكى و برخى مرانز روزانه و شبانه روزى اعصاب و روان تحت يوشش

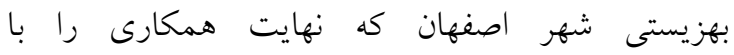
يُزوهشخران داشتهاند، تشكر و قدردانى مىنمايند. مقاله حاضر بركرفته از بايان نامه كارشناسى ارشد رشته روان

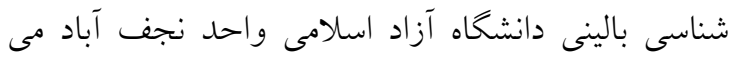
باشد.

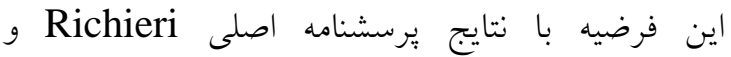

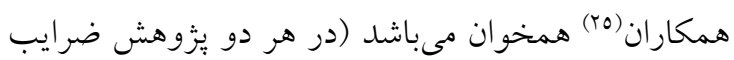

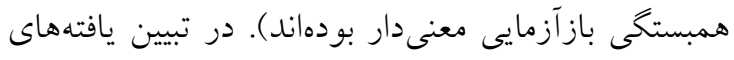

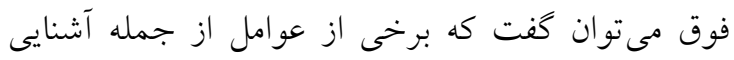

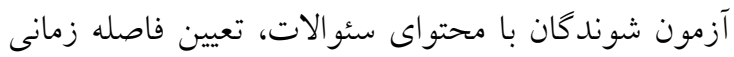
كوتاه دو هفتهاى و همجنين برخى خصوصيات و تغيير

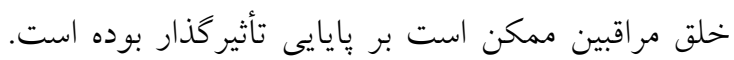

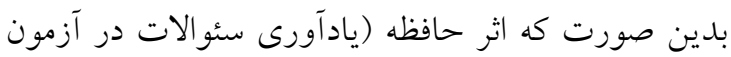
كه سبب ايجاد نوعى خطاى همبستكى يا غير تصادفى

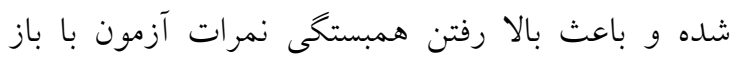

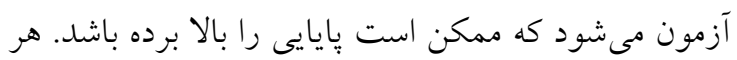
جند اثر خستخى و اثرات ناشى از تغييرات واقعى تأثيرى

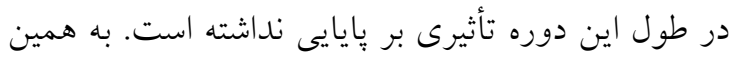

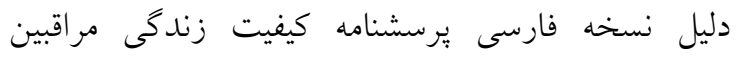
بيماران اسكيزوفرنى از بايايى بازآزمايى برخوردار است.

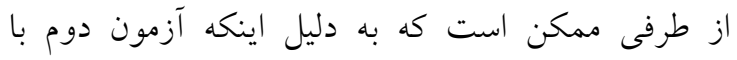

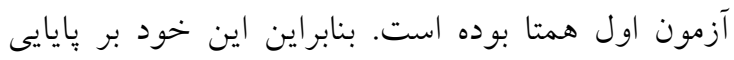
مؤثر بوده است و فاصله زمانى اجراى فرم هاى همتا زياد

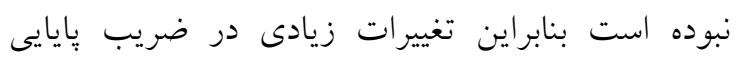
بازآزمايى مشاهده نشد. با توجه به نتايج تحليل عاملى و و نئي

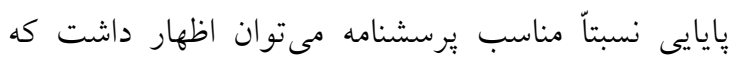
نسخه فارسى ترجمه شده با مؤلفههاى روانسنجى ابزار

\section{References}

1. Zauszniewski JA, Bekhet AK. Factors associated with the emotional distress of women family members of adults with serious mental illness. Arch Psychiatr Nurs. 2014;28(2):102-7.

2. American Psychiatric Association. Diagnostic and statistical manual of mental disorders (DSM5®). American Psychiatric Pub; 2013 May 22.

3. Sadock BJ, Sadock VA, Ruiz P. Kaplan and Sadock's Synopsis of Psychiatry: Behavioral Sciences/Clinical Psychiatry. 11 $1^{\text {th }}$ ed. New York: Wolters Kluwer;2014.

4. Momeni F, Raghibdoost S. The Relation between Language and Thought in Auditory Verbal Hallucination and Delusional Speech of Schizophrenic Patients: The Analytic Philosophy Perspective. Journal of Zabanshenakht ;2014,4(8):165-78. [Persian]

5. Azad H. Psychological Pathology,Tehran: Besat; 2013. [Persian]

6. Bobes J, Arango C, Garcia-Garcia M, Rejas J. Prevalence of negative symptoms in outpatients with schizophrenia spectrum disorders treated with antipsychotics in routine clinical practice: findings from the CLAMORS study. J Clini Psychiatry. 2010;71(3):280.

7. Haresabadi M, Bibak B, Bayati M, Arki M, Akbari H. Assessing burden of family caregivers of patients with schizophrenia admitted in Imam Reza Hospital-Bojnurd 2010. Journal of North Khorasan University of Medical Sciences. 2012;4(2):165-71. [Persian] 
8. Bulger MW, Wandersman A, Goldman CR. Burdens and gratifications of caregiving: Appraisal of parental care of adults with schizophrenia. Am J Orthopsychiatry. 1993;63(2):255-65.

9. Gülseren L, Cam B, Karakoç B, Yiğit T, Danacı AE, Çubukçuoğlu Z, Taş C, Gülseren S, Mete L. The perceived burden of care and its correlates in schizophrenia. Turk Psikiyatri Derg. 2010;21(3):203-12.

10. Esmkhani M, Khalkhali HR, Ahangarzadeh Rezaei S. The Effect of Adherence to Treatment Intervention Porgram on the Quality of Life of Schizophrenia Patients. The J Urmia Nurs Midwifery Fac. 2017;15(8):595-604. [Persian]

11. Chou KR. Caregiver burden: a concept analysis. J Pediatr Nurs. 2000;15(6):398-407.

12. Pasdar Y, Eizadi N, Safari R. Effective factors on the quality of life in female students of Kermanshah university of medical sciences. Journal of Ilam university of medical sciences. 2013;21(6):33-41. [Persian]

13. Bulger MW, Wandersman A, Goldman CR. Burdens and gratifications of caregiving: David E. Biegel (Doctoral dissertation, Ph. D., et al. 165).

14. Chan SW. Global perspective of burden of family caregivers for persons with schizophrenia. Arch Psychiatr Nurs. 2011;25(5):339-49.

15. Rochester S. Crazy talk: A study of the discourse of schizophrenic speakers. Springer Science \& Business Media; 2013 Apr 17.

16. Lysaker PH, Dimaggio G, Buck KD, Carcione A, Nicolò G. Metacognition within narratives of schizophrenia: associations with multiple domains of neurocognition. Schizophrenia research. 2007;93(1-3):278-87.

17. Sass LA. Self-disturbance and schizophrenia: structure, specificity, pathogenesis (current issues, new directions). Schizophrenia research. 2014;152(1):5-11.

18. Chime N, Malakoti SK, Pennaghi L, Ahmadabadi Z, Nojomi M, Ahmadi Tonekaboni A. Factors affecting burnout and mental health among caregivers of patients with schizophrenia. Journal of Family Research. 2008;4(15):277-92. [Persian]

19. Hosseiniamin, SN, Seyyed Mirzaei SM, Edrisi A. A Study of the Quality of Life and Factors Affecting It (Case Study: Citizens of Tehran). Quarterly of Welfare and Social Development Planning. 2016,7(27):34-47. [Persian]

20. Rabbani Khorasgani A, Kianpour M. The proposed model for measuring the quality of life, Journal of the Faculty of Literature and Humanities. 1998;15(4):.67-108. [Persian]

21. Ghaffari GH, Omidi R. Quality of life, social development Index. Tehran: Publication headband. 2009. [Persian]

22. Azimi L, Bajlan A. Quality of Life Studies. Arak: Nevisande; 2009. [Persian]

23. Bond, J, Corner, L. The Quality of Life and the Elderly. Translator Seyyed Hossein Mohagheghi Kamal. Tehran:Tehran University; 2014. [Persian]

24. Bahmani B, Tamadoni M, Asgari M. Quality of life and its relation with religious attitude and academic performance of students of Islamic Azad University, South of Tehran. Journal of Teb and Tazkiye. 2004;(53):32-44. [Persian]

25. Richieri R, Boyer L, Reine G, Loundou A, Auquier P, Lancon C, Simeoni MC. The Schizophrenia Caregiver Quality of Life questionnaire (S-CGQoL): development and validation of an instrument to measure quality of life of caregivers of individuals with schizophrenia. Schizophrenia research. 2011;126(1-3):192-201.

26. Skevington SM, Lotfy M, O'Connell K2. The World Health Organization's WHOQOL-BREF quality of life assessment: psychometric properties and results of the international field trial. A report from the WHOQOL group. Quality of life Research. 2004;13(2):299-310.

27. Goldenberg H, Goldenberg I, Family theraphy:An overview, $8^{\text {th }}$ ed. United states of America:cengage learning; 2012. P:2-4. 


\section{بيوستها}

هنجاريابى نسخدى فارسى يرسش نامه كيفيت زندكى مر اقبين بيمار ان واجد تشخيص اسكيزوفرنى

شغل:

تعداد فرزندان بيمار:
تحصيلات:

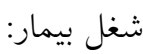

وضعيت تأهل:

وضعيت تأهل بيمار:

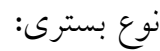

\begin{tabular}{|c|c|c|c|c|}
\hline \\
\hline \multicolumn{5}{|c|}{ 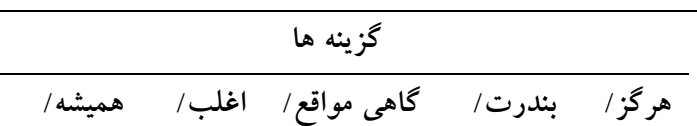 } \\
\hline خيلى زياد & زياد & تا حدودى & & اصلا \\
\hline
\end{tabular}

آيا شما احساس ناراحتى وافسردگى مى كنيد؟

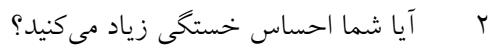

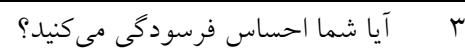

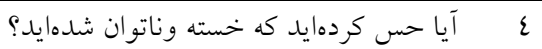

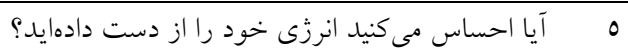
1

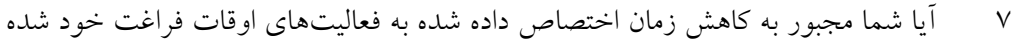

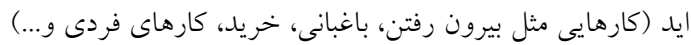
A ترك كردهايد خجالت كشيدايد؟

9 ه و آيا شما اين احساس را داشتهايد كه زمان كافى براى بقيه خانو اده خود اختصاصندادهايد؟ أl آيا شما احساس كردهايد كه فردى آزاد نيستيد؟

11

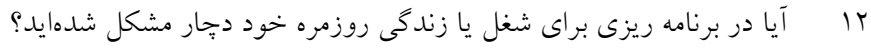

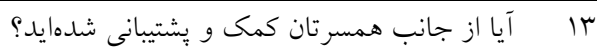

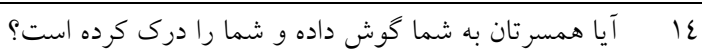
10

17

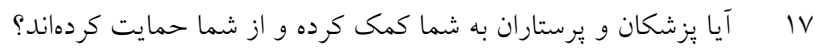

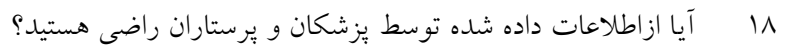

19

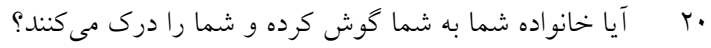

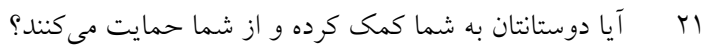

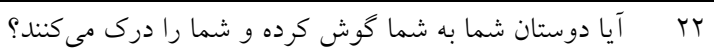
rr T آيا زمانى كه به ديارتمانها و بخش هاى اجر ايى مراجعه مى كنيد به خاطر بيمارى فرزندتان

با مشكل مواجه مى شويد؟

r

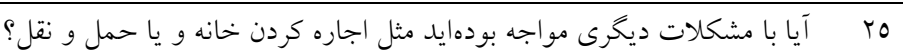




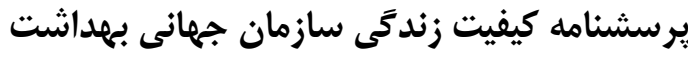

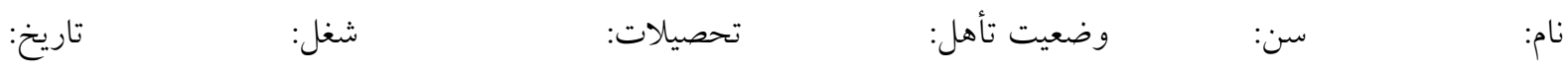
سئوالات زير را به دقت بخوانيد و اولين گزينهاى كه به ذهنتان مىرسد علامت بزنيد.

\begin{tabular}{|c|c|c|c|c|c|c|}
\hline بسيار خوب & خوب & 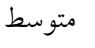 & بد & 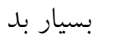 & جملات & \\
\hline ० & $\varepsilon$ & r & r & 1 & كيفيت زندگى خود را جِكونه ارزيابى مى كنيد & 1 \\
\hline
\end{tabular}

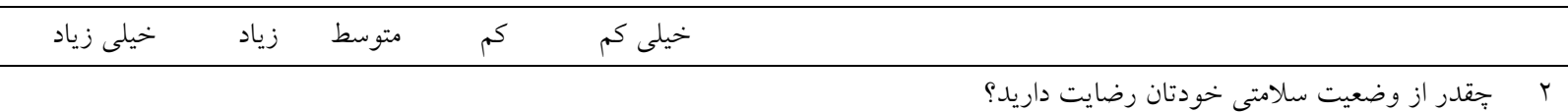

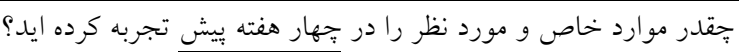

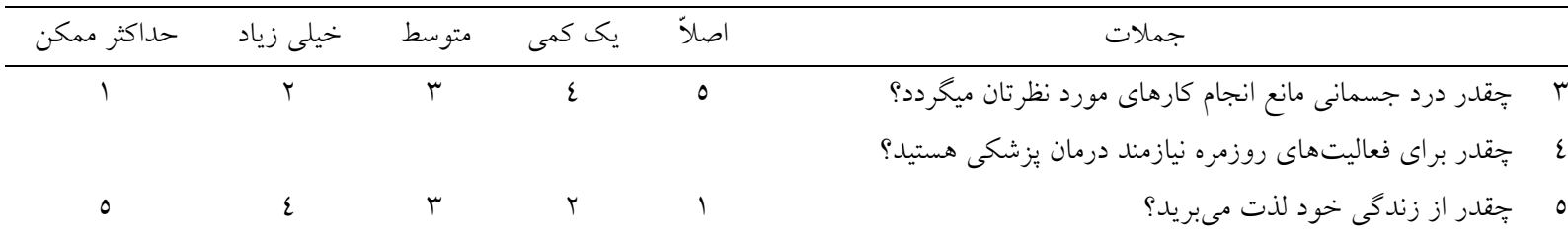

ج جقدر احساس مى كنيد زندگى شما معنى دار است؟

جقدر قادر به تمركز هستيد؟ V V

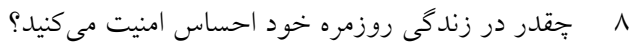

9

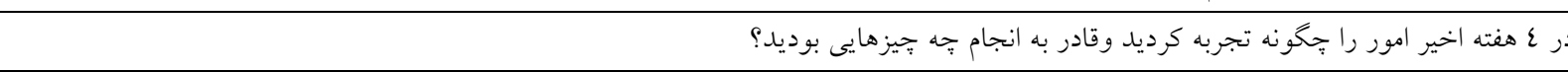

\begin{tabular}{|c|c|c|c|c|c|c|}
\hline كاملا & اكثرا & 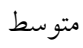 & كمى & اصلا & جملات & \\
\hline \multirow[t]{6}{*}{0} & $\varepsilon$ & r & r & 1 & آيا براى زندگى روزمره خود انرزى كافى داريد؟ & $1 \cdot$ \\
\hline & & & & & آيا از ظاهر خودتان راضى هستيد؟ & 11 \\
\hline & & & & & آيا براى رفع نيازهاى خود يول كافى داريد؟ & ir \\
\hline & & & & & جقدر به اطلاعات روزمره مورد نياز خود دسترسى داريد؟ & ir \\
\hline & & & & & به جهه ميزان امكان فعاليتهاى تفريحى داريد؟ & $1 \varepsilon$ \\
\hline & & & & & جقدر مى توانيد جابه جا شويد و تحرك داشته باشيد؟ & 10 \\
\hline
\end{tabular}

\begin{tabular}{|c|c|c|c|c|c|c|}
\hline خيلى زياد & زياد & 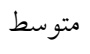 & كم & 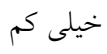 & 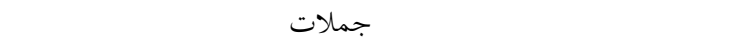 & \\
\hline \multirow[t]{10}{*}{0} & $\varepsilon$ & r & r & 1 & جقدر از وضعيت خواب خود راضى هستيد؟ & 17 \\
\hline & & & & & جقدر از توانايى هاى خود در انجام فعاليتهاى روزمره راضى هستيد؟ & IV \\
\hline & & & & & جقدر از توانايىهاى خود براى كار كردن (اشتغال) رضايت داريد؟ & 11 \\
\hline & & & & & جقدر از خودتان رضايت داريد؟ & 19 \\
\hline & & & & & جقدر از روابط شخصى خود رضايت داريد؟ & $r \cdot$ \\
\hline & & & & & جقدر از روابط عاطفى با همسر يا ديخران رضايت داريد؟ & r) \\
\hline & & & & & جقدر از حمايتى كه از دوستان و فاميل دريافت مى كنيد رضايت داريد؟ & rt \\
\hline & & & & & جقدر از شرايط محل سكونت خود رضايت داريد؟ & $r$ \\
\hline & & & & & جقدر از دسترسى خود به خدمات بهداشتى درمانى رضايت داريد؟ & $r \varepsilon$ \\
\hline & & & & & جقدر از وضعيت رفت وآمد خود احساس رضايت داريد؟ & ro \\
\hline
\end{tabular}

\begin{tabular}{|c|c|c|c|c|c|c|}
\hline هميشه & اكثرا & نسبتا & بندرت & هر كز & 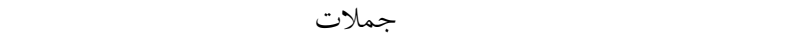 & \\
\hline 1 & r & $r$ & $\varepsilon$ & 0 & جقدر دجار حالاتى مانند غمخينى، ناميدى، اضطراب و افسردگى مىشويد؟ & $r 7$ \\
\hline
\end{tabular}

